\title{
Beginning of the Miocene Climatic Optimum in Central Europe in sediment archive of the Most Basin, Czech Republic
}

\author{
Tomáš Matys Grygar, Karel Mach, Magdalena Koubová, Mathieu Martinez, \\ Karel Hron \& Kamila FaČEvicová
}

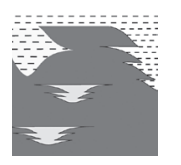

\begin{abstract}
The Most Basin (Czech Republic) offers an extraordinarily detailed archive of the continental environment in Central Europe $\left(\mathrm{ca} .50^{\circ} \mathrm{N}\right)$ in the period around the beginning of the Miocene Climatic Optimum. The sediments were studied by magneto-, chemo-, and cyclostratigraphy. Novel proxies for chemical weathering intensity were derived from $\mathrm{K} / \mathrm{Al}$ concentration ratios and $\mathrm{Mg} / \mathrm{Al}$ concentration ratios corrected for autochthonous carbonate content using an isometric log-ratio methodology and robust regression (RR). The correction confirmed that the association of chemical weathering maxima (lows in $\mathrm{K} / \mathrm{Al}$ or $\mathrm{Mg} / \mathrm{Al}$ ) with eccentricity, obliquity, or precession maxima were affected by sediment grain size to only a minor degree. The orbital control allowed for the refinement of a magnetic-polarity-based depth-age model to unprecedented resolution. The timing of the basin development after the peat swamp flooding was confirmed; it started in the C5Dr.2r subchron, intensified in the C5Dn.1n subchron over several tens of kyr, and spread over the entire basin in the early part of C5Dr.1r. The expression of orbital cycles in weathering proxies changed abruptly near 17.07 and $16.90 \mathrm{Ma}$, in close temporal proximity to two step-like changes in global marine $\delta^{18} \mathrm{O}$ records between 17.2 and 16.9 Ma. The sensitivity of weathering intensity in the Most Basin to orbital forcing decreased coevally with the initial floods of the Columbia River Basalt Group and disruptions of the global $\delta^{13} \mathrm{C}$ record near the C5Dr/C5Dn reversal at around 16.6 Ma. Ratios $\mathrm{K} / \mathrm{Al}$ and $\mathrm{Mg} / \mathrm{Al}$, either raw or carbonate corrected, can be recommended for the study of continental basin sediments. $•$ Key words: lacustrine sediments, stratigraphy, orbital forcing, weathering proxies, geomagnetic reversals.
\end{abstract}

Matys Grygar, T., Mach, K., KoubovÁ, M., Martinez, M., Hron, K. \& FaČEvicovÁ, K. 2021. Beginning of the
Miocene Climatic Optimum in Central Europe in sediment archive of the Most Basin, Czech Republic. Bulletin of
Geosciences 96(1), 61-81 (13 figures, 3 tables). Czech Geological Survey, Prague. ISSN 1214-1119. Manuscript
received April 17, 2020; accepted in revised form October 20, 2020; published online December 13, 2020; issued
January 10, 2021.

Tomáš Matys Grygar, Institute of Inorganic Chemistry of the Czech Academy of Sciences, Řež 1001, 25068 HusinecŘež, Czech Republic; grygar@iic.cas.cz • Karel Mach, North Bohemian Mines, j.s.c., 5. května 2013, 41801 Bílina, Czech Republic • Magdalena Koubová, Czech Geological Survey, Geologická 6, 15200 Prague 5, Czech Republic • Mathieu Martinez, UMR 6118 Geosciences Rennes, Observatoire des Sciences de l'Univers Rennes, Université de Rennes 1, Campus de Beaulieu, 35042 Rennes Cedex, France • Karel Hron \& Kamila Fačevicová, Department of Mathematical Analysis and Applications of Mathematics, Faculty of Science, Palacký University, 17. listopadu 12, 77146 Olomouc, Czech Republic

The Miocene Climatic Optimum (MCO; $c a .17$ to $15 \mathrm{Ma}$ ) represents a time of global warming within the persistent Cenozoic cooling (Zachos et al. 2001). The MCO brought thermophilic vertebrate species into central Europe (Böhme 2003), and was terminated by an abrupt return to global cooling. In spite of considerable research efforts, climate evolution in the pre-MCO and early MCO periods has not been fully understood. The southern polar ice cap (Antarctic Ice Sheet, AIS) was considerably reduced during the MCO (Gasson et al. 2016, Levy et al. 2016), perhaps due to a coincidence of particular paleogeographic (Gasson et al. 2016) and orbital settings
(De Vleeschouwer et al. 2017), and possibly acting in coincidence with long carbon cycles (Liebrand et al. 2016, Valero et al. 2016). The global pre-MCO climate could also have responded to some specific, yet unidentified trigger(s). A volcanic hypothesis was proposed (Courtillot \& Renne 2003), tested, rejected based on a critical discussion on Ar-Ar dating precision (Barry et al. 2010, Armstrong McKay et al. 2015), and finally revoked after new dating and upon addressing all uncertainties of the Miocene time scales (Kasbohm \& Schoene 2018). An increase in atmospheric $\mathrm{CO}_{2}$ was assumed to have been the MCO trigger; evidence for this was searched for in 


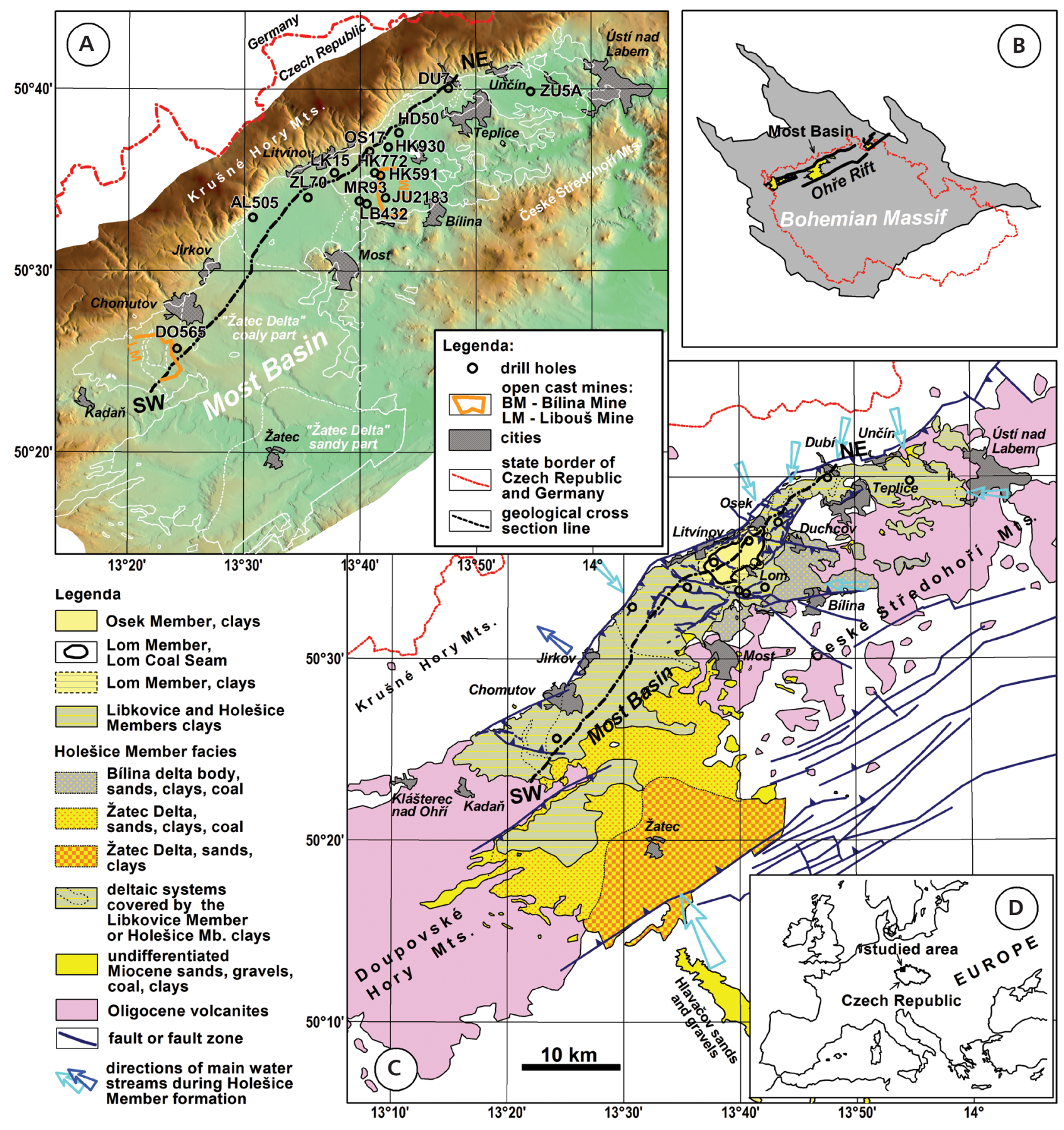

Figure 1. Maps of the study area with: A- position of cores and basin cross-section shown in Fig. 2; B - position of the Most Basin within Bohemian Massif (grey area); C - geological map; D - position of study area in Europe.

fossil plant records (Kürschner et al. 2008), but eventually denied due to inconsistencies between models and observations (Levy et al. 2016, Ji et al. 2018). A possible change in the altitude of the AIS surface has also been discussed (Levy et al. 2016), but the Antarctic paleotopography is not known. More detailed archives are needed to fully understand the pre-MCO period, in particular in continental domains, where climate records were not impacted by changes in oceanic circulation and chemistry of water masses, which reportedly resulted in hiatuses in marine sedimentary records at $c a .17 .0 \mathrm{Ma}$ (Miller et al. 2017). As a consequence of these hiatuses, there are multiple potential time scales for the $\delta^{18} \mathrm{O}$ shift that is considered to be the onset of the MCO (Holbourn et al. 2015, Kochhann et al. 2016, Miller et al. 2017), with a possible misfit of several hundred kyr. Miller et al. (2017) 


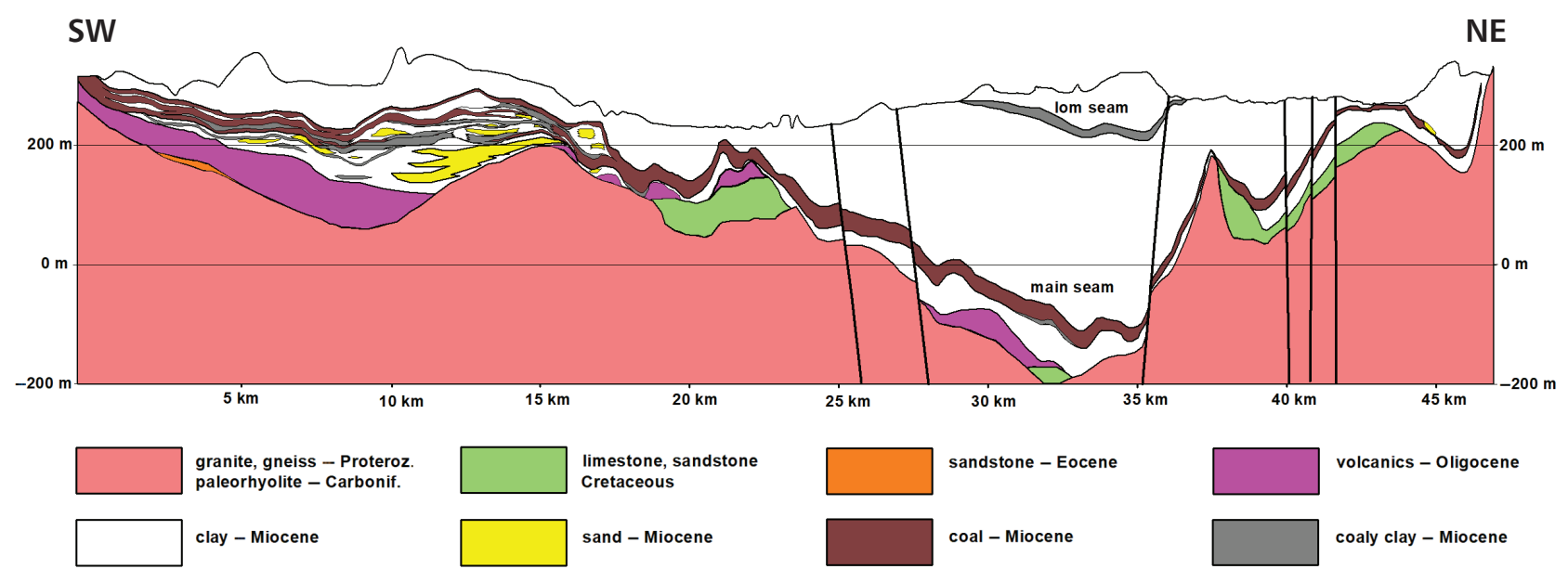

Figure 2. SW-NE cross section of the Most Basin, the position of cross section is shown in Fig. 1.

stated that the record from the equatorial Pacific Ocean, Site U1338 (Kochhann et al. 2016), is lagged by $405 \mathrm{kyr}$ compared to the record from the southern Indian Ocean, site 751 (Miller et al. 2017), between 17 and $18 \mathrm{Ma}$. This misfit can be evaluated by an independent record.

The Most Basin in northwestern Czech Republic (map in Fig. 1 and cross section in Fig. 2) hosts a detailed continental sedimentary record of the early stages of the MCO. The Most Basin record was formed by lacustrine sedimentation spanning a $c a$. 1.7 Myr interval beginning ca. 17.7 Ma (Matys Grygar et al. 2014, 2017b, 2019a; Fig. 3). To fully take advantage of the stratigraphic uniqueness of the basin, a detailed study of stratigraphic correlation of the chemo-, cyclo-, and magnetostratigraphic records from the basin was performed. Chemo- and cyclostratigraphic studies of the Most Basin have mainly been based on geochemically normalised $\mathrm{K}$ concentrations (Matys Grygar et al. 2019b), which potentially carry information on chemical weathering intensity in the sediment source area (Buggle et al. 2011, Garzanti et al. 2013), but which also bear certain grain-size contributions (Matys Grygar et al. 2019b). Recently, normalised Mg concentrations have also been proposed as a weathering proxy (Dinis et al. 2017). The major components of the the clay mineral assemblage in the Most Basin sediments are kaolinite and illite/smectite interstratified minerals. Chemical weathering of such mixtures would convert convert illite structures to smectite and then both illite/ smectites minerals to kaolinite, which would both lead to liberation of $\mathrm{K}^{+}$and $\mathrm{Mg}^{2+}$ ions, i.e., decrease in $\mathrm{K}$ and $\mathrm{Mg}$ concentrations in the solid phase. The ability to fully utilise all weathering proxies depends on further developments, in particular to account for the particle grain size (Tanaka \& Watanabe 2015, Matys Grygar et al. 2019 b), or alternatively by proof that the proxy is grainsize independent, because sediment coarseness may also reflect numerous non-climatic factors, such as autogenic cycles in fluvial and lacustrine deposition. The processing of chemical composition data should further respect the specific mathematical nature of the data (PawlowskyGlahn et al. 2015, Fačevicová et al. 2016).

Cyclostratigraphy has recently proliferated due to its potential to tune age models of continuous sediment strata more precisely than radiometric methods. It has successfully been employed in the refinement of time scales in stratigraphic boundaries and global events (Martinez et al. 2013, Beddow et al. 2018, Ait-Itto et al. 2018). For example, the Neogene polarity time scales require refinement by orbital tuning (Kochhann et al. 2016, Beddow et al. 2018), while the most broadly used
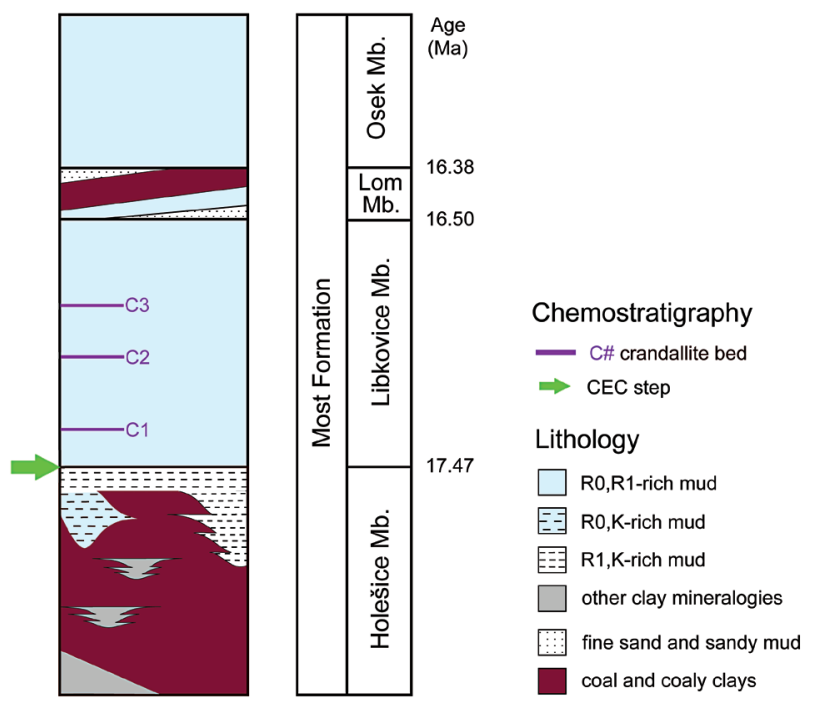

Figure 3. Local stratigraphy of the Most Basin with position of crandallite beds C\#. Dating of the local stratigraphic boundaries was taken from Matys Grygar et al. (2019a). 
ATNTS2012 (Astronomically Tuned Neogene Time Scale; Hilgen et al. 2012), has not been astronomically tuned in the pre-MCO and early MCO periods of time. Simultaneously, cyclostratigraphy still requires refinement of mathematical and statistical tools and the development of robust criteria for its users (Vaughan et al. 2011, Smith 2019), in particular due to inevitable stratigraphic distortion and 'contamination' of the orbital signal by non-climatic factors in real sedimentary records (Meyers 2019, Matys Grygar 2019). Statistical tests might be insufficient to confirm the existence of orbital signatures. We thus propose supporting the statistical tests by extensive lateral correlations (the climatic signal should be spatially invariant in the sedimentary basin) and by refinement of proxies, which are subjected to spectral analyses. In clastic sedimentary archives, the second point should include separation of grain-size control, provenance changes, and possible diagenetic features from the desired paleoenvironmental signal, i.e. the removal of contamination of orbital signals sensu Meyers (2019).

The aforementioned challenges have been addressed in the continuing study of the Most Basin. Further evaluations of the sedimentary records were performed from the central and northern parts of the Most Basin to reveal details on the basin development and to fill gaps in preceding studies, such as poor magnetostratigraphy in the earliest stages of basin-wide clastic deposition over the former peat swamp at ca. 17.6 Ma (Mach et al. 2014, Matys Grygar et al. 2017a) and the limited number of continuous long cores. The intention was to improve the existing weathering (paleoenvironmental) proxies, the $\mathrm{K} / \mathrm{Al}$ and $\mathrm{Mg} / \mathrm{Al}$ ratios, via their grain-size and carbonate corrections, which could facilitate future studies of continental sediments (Matys Grygar et al. $2019 \mathrm{~b}$ ). This work should also refine the timing of abrupt environmental changes in the Most Basin, which could be relevant for the onset and early stages of the MCO.

\section{Settings}

\section{Paleoenvironment}

The Most Basin is situated in the north-west of the Czech part of the Bohemian Massif. With an area of $870 \mathrm{~km}^{2}$ of erosion remnants of the basin floor, it is the largest sedimentary basin in the Ohře Rift structure (Rajchl et al. 2009) of the upper Oligocene to lower Miocene age. The maximal thickness of the sedimentary fill of the Miocene Most Formation is nearly 500 metres, between the cities of Osek and Lom, where the complete stratigraphic column of sediments of the Most Formation (Fig. 3) was preserved. It starts from the late Oligocene to early Miocene (the Duchcov Member), continuing to the areally most extensive Holešice Member, including the intensively exploited Main Coal Seam. Subsequent, prevalently lacustrine basin fills of the Libkovice, Lom, and Osek members can be identified in successively shrinking erosional relics (Fig. 2).

Paleogeographic settings of the Most Basin in the early stage of the swamp-to-lake transition were described by Mach et al. (2014), mainly using heavy mineral associations in coarse clastic material in the overburden of the Main Coal Seam of the Holešice Member. An extensive borehole database of the North Bohemian Mines compiled since 1980 was also evaluated by Mach et al. (2014), together with the atlas of the Most Basin cross sections. Several areas with specific compositions of clastic material input to the basin were identified (Mach et al. 2017). The best known local fluvial-deltaiclacustrine system, the Bílina Delta, is located in the eastern border of the Most Basin (Fig. 1). Its sediment body covers an area of $c a .10 \times 5 \mathrm{~km}$ and a maximal thickness of $150 \mathrm{~m}$. It onlaps on the Main Coal Seam, showing the coexistence of a swamp with a local water body (Mach et al. 2013) and considerable potential for generation of the accommodation space via compaction of the peat matter by fluvial clastics (Rajchl et al. 2008, Mach et al. 2013). Heavy minerals in the Bílina Delta sands contain andalusite association from the south-western part of the Bohemian Massif mixed with a tourmaline-zircon association mainly from Upper Cretaceous sediments of the northern half of the Bohemian Massif (Mach et al. 2014). The silty sediments of distal parts of the Bílina Delta are distinguished by their low cation exchange capacity (CEC; Matys Grygar et al. 2014). Several sandy belts oriented from the north-western border of the Most Basin toward the south-east were found with heavy mineral associations completely free of andalusite, but with some minerals typical of ore deposits of the Krušné Hory (Ore) Mountains, such as topaz and apatite (Mach et al. 2014). The largest of these southward flowing streams were located near the cities of Osek, Duchcov, and Teplice (Fig. 1). Their lobes, with maximal thicknesses of up to $60 \mathrm{~m}$, extend to $c a .2 / 3$ of the basin width in this area. Another lake was situated in the western part of the basin in the area between Chomutov and Kadañ (south of the city of Most). Sediments of this lake are distinguished by their high CEC (Matys Grygar et al. 2017a); they represent the lowermost strata of the overburden in the Libouš Mine, a part of the Nástup Mines Tušimice (e.g. in the DO565 core, Matys Grygar et al. 2019a). The thickness of these sediments reaches $20 \mathrm{~m}$ in the axis of the Chomutov-Kadan̆ lobe.

The time interval characterised by several isolated lakes within the extensive peat swamp was followed by the basin-wide lacustrine phase. The existing peat layer in the basin floor was compressed to a fraction of its 


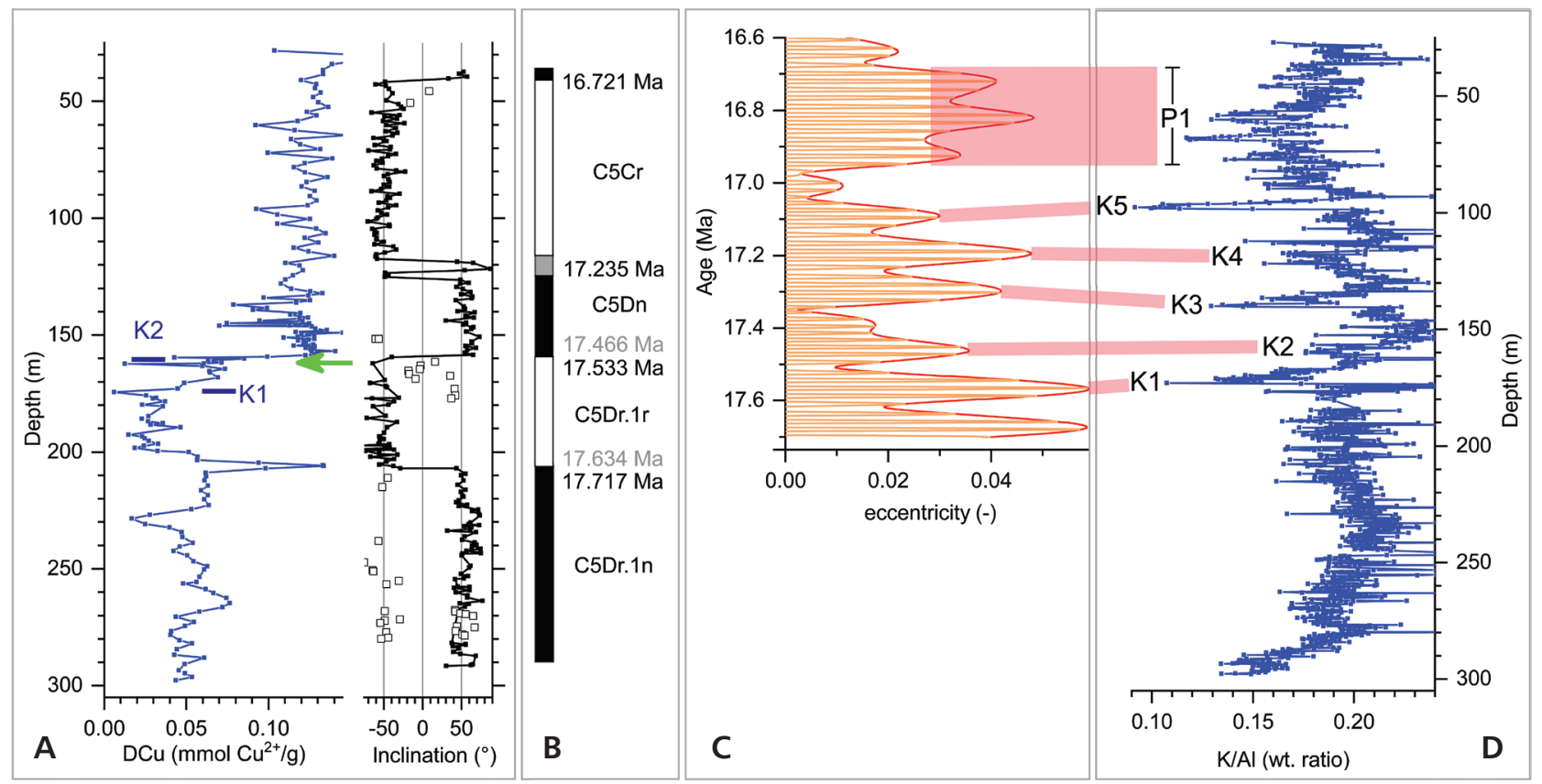

Figure 4. MR93 core analyses and construction of its depth-age model. Local stratigraphy, major chemostratigraphic markers and experimental magnetic polarity zones (A), K\# are prominent K minima, green arrows show the depth of the CEC step. Magnetic reversals assigned to polarity timescales (B), black letters are reversal ages in ATNTS2012 (Hilgen et al. 2012), grey letters reversal ages by Kochhann et al. (2016). Eccentricity and precession in astronomical solution by Laskar et al. (2004) (C) vertically positioned to correspond roughly to the timing of the polarity reversals. The Most Basin record (D), assignment of K/Al minima K1 to K4 to eccentricity maxima and P1 period to the triplet of high-eccentricity cycles. Note that panels A and D have the same depth scales and vertical positions.

original thickness by the mass of the clastic deposits and the water column (Mach 2003, Rajchl et al. 2008), which, among other consequences, resulted in locally specific and temporally variable initial deposition rates. The final large lake overflowed in the vicinity of Jirkov city toward the north-west (Mach et al. 2014). The present-day steep crest of the Krušné Hory Mountains did not exist in the Miocene, as evidenced by the lack of very coarse sediments on the north-western borders of the basin in the lacustrine period.

\section{Local chemostratigraphic scheme}

A local chemostratigraphic scheme for the Libkovice Member has been established (Matys Grygar \& Mach 2013) and tested for numerous cores covering the entire Most Basin (Matys Grygar et al. 2014, 2017b, 2019a). This scheme provides laterally persistent horizons, part of which are summarised in Figs 2 and 3. Among its components, there are variations in $\mathrm{K} / \mathrm{Al}$ or $\mathrm{K} / \mathrm{Ti}$ ratios (Fig. 4) controlled by orbital forcing (Matys Grygar et al. 2014, 2019a), calcium aluminium phosphate (crandallite, Sr bearing) beds $\mathrm{C} 1$ to $\mathrm{C} 3$ (centimetre-scale thickness) with basin-wide lateral stability and still-unknown triggers, and Sr peaks (metre-scale thickness) with limited lateral stability at the basin scale but excellent performance in terms of correlations between neighbouring cores (Matys Grygar et al. 2017a). Crandallite was attributed to volcanic fallout by local geologists; however, evidence for this is absent (Matys Grygar et al. 2017a). Crandallite can beformed by chemical reaction of (biogenic) calcium phosphates and clay minerals under acidic conditions (Dill 2001) in situ in sediments. The $\mathrm{Sr}$ for the crandallite was scavenged from lake water, and thus the strata just above their beds were Sr-depleted; this can be used to infer the position of the crandallite bed, even if the bed itself was not recovered during coring.

The lower boundary of the Libkovice Member was associated with the CEC-step horizon, an abrupt increase in CEC, or the exceedance of the gradually increasing $\mathrm{CEC}$ over a threshold value around $0.1 \mathrm{mmol} \mathrm{Cu}^{2+} / \mathrm{g}$. The CEC increase reflects the dominance of the highexpandable illite-smectite interstratified clay mineral (I/S), with a prevalence of smectite layers (I/S interstratified mineral R0) in the Libkovice Member clay assemblage, while kaolinite and low-CEC I/S with a prevalence of illite layers ( $\mathrm{I} / \mathrm{S}$ interstratified mineral $\mathrm{R} 1$ ) dominates in the underlying Holešice strata (Matys Grygar et al. 2017a). The reason for this switch in clay mineral assemblage remains enigmatic. It was not caused by burial diagenesis (Dellisanti et al. 2010), because the Most Basin sediment was buried very shallowly, and its organic matter remained thermally immature, with vitrinite reflectance 
ca. 0.3 and with no change between the Holešice and the Libkovice members (Havelcová et al. 2015). Previous work also showed that the high-expandable I/S is present in the Holešice Member sediments just above the Main Coal Seam in some depocentres (Tušimice and Ústí nad Labem areas). The CEC variations in the sediments are thus further corroborated by this work.

\section{Methods}

\section{New and re-visited drill cores}

The locations of the drill cores discussed in this work are shown in Fig. 1, and their major features and coordinates are summarised in Tab. 1. New drill cores were retrieved in the northern part of the basin (DU7, HK930) and in the main basin depocentre northwest (LK15) and west (JU2183, LB432, and ZL70) of the Bílina Mine area. JU2183, MR93, and LB432 were retrieved close to the Bílina Mine to cover the earliest stages of the Bílina proto-lake, the magnetostratigraphy of which needed reinterpretation in the lowermost part of the HK591 core, as discussed by Matys Grygar et al. (2019a). Several previously described drill cores were also revisited in this work. Cores DO565, HK772, and OS17 were introduced originally in Matys Grygar et al. (2017a, b, 2019a) and reused herein. In the case of LB432, only its geochemistry was reported (Matys Grygar et al. 2019b).

\section{Chemical analyses}

E,lemental analysis was performed by energy-dispersive X-ray fluorescence spectroscopy (XRF) using an Epsilon
3X instrument (PANalytical, the Netherlands). The analysis was performed on loose powdered sediments (Pulverisette planetary micromill, Fritsch, Germany) in PANalytical measuring cells with Mylar foil bottoms. The analytical signals were calibrated using certified reference materials as described previously (Matys Grygar et al. 2019a).

Cation exchange capacity (CEC) was determined using a $[\mathrm{Cu}(\text { trien })]^{2+}$ complex as described previously (Meier \& Kahr 1999, Grygar et al. 2009). The results were expressed as the decrease of $[\mathrm{Cu}(\text { trien })]^{2+}$ in solution after ion exchange, $\Delta \mathrm{Cu}$ in $\mathrm{mmol}$ as $[\mathrm{Cu}(\text { trien })]^{2+} / \mathrm{g}$ sample; the conventional $\mathrm{CEC}$ in meq/100 $\mathrm{g}$ would thus be equivalent to $200 \mathrm{x}$ the $\Delta \mathrm{Cu}$ given in this work. The CEC step (Figs 3,4 ) was proposed as the boundary between the Holešice and Libkovice members (Matys Grygar \& Mach 2013).

\section{Diffraction analyses}

Clay mineral analysis was performed with conventional oriented preparations with size fractions of $<2 \mu \mathrm{m}$, prepared by sedimentation in distilled water and pipetting the suspension onto Si slides. X-ray diffraction (XRD) patterns were acquired using a Bruker D8 Advance diffractometer $(\mathrm{CuK} \alpha$, primary and secondary Soller slits $2.5^{\circ}$, detector Lynxeye XE) with automatic divergence slit (ADS; $10 \mathrm{~mm}$ ). The XRD patterns were recorded in the range of $2.8-50^{\circ} 2 \theta$, with angular steps of $0.019^{\circ} 2 \theta$ and time per step of $0.8 \mathrm{~s}$, in air-dry (ad) state and after ethylene glycol solvation (at $60{ }^{\circ} \mathrm{C}$ for $8 \mathrm{~h}$ ). The XRD patterns of the glycolated preparations were modelled with the Sybilla software (Chevron ETC proprietary). The Sybilla software provides full-profile fitting of experimental XRD patterns of 001 reflections following

Table 1. List of cores, their coordinates, their total depths, and thickness of the lacustrine sediments above the Main Coal Seam addressed in this paper.

\begin{tabular}{|c|c|c|c|c|}
\hline Drill core & Area & $\begin{array}{c}\text { Coordinates } \\
\text { WGS-84 }\end{array}$ & $\begin{array}{l}\text { Depth } \\
\text { (m) }\end{array}$ & $\begin{array}{c}\text { Thickness } \\
\text { (m) }\end{array}$ \\
\hline AL505 & W of Litvínov & $50^{\circ} 32^{\prime} 50.525^{\prime \prime} \mathrm{N}, 13^{\circ} 30^{\prime} 45.322^{\prime \prime} \mathrm{E}$ & 102 & 95 \\
\hline DO565 & S of Chomutov & $50^{\circ} 25^{\prime} 36.838^{\prime \prime} \mathrm{N}, 13^{\circ} 24^{\prime} 14.268^{\prime \prime} \mathrm{E}$ & 160 & 104 \\
\hline DU7 & in Dubí & $50^{\circ} 39^{\prime} 57.367^{\prime \prime} \mathrm{N}, 13^{\circ} 47^{\prime} 39.446^{\prime \prime} \mathrm{E}$ & 121 & 99 \\
\hline HK930 & SE of Osek & $50^{\circ} 36^{\prime} 43.338^{\prime \prime} \mathrm{N}, 13^{\circ} 42^{\prime} 26.741^{\prime \prime} \mathrm{E}$ & 224 & 192 \\
\hline JU2183 & W of Bílina & $50^{\circ} 33^{\prime} 55.609^{\prime \prime} \mathrm{N}, 13^{\circ} 42^{\prime} 12.921^{\prime \prime} \mathrm{E}$ & 128 & 74 \\
\hline LB432 & S of Lom & $50^{\circ} 33^{\prime} 35.766^{\prime \prime} \mathrm{N}, 13^{\circ} 40^{\prime} 35.595^{\prime \prime} \mathrm{E}$ & 292 & 124 \\
\hline LK15 & SE of Litvínov & $50^{\circ} 35^{\prime} 17.988^{\prime \prime} \mathrm{N}, 13^{\circ} 37^{\prime} 47.202^{\prime \prime} \mathrm{E}$ & 351 & 325 \\
\hline MR93 & S of Lom & $50^{\circ} 33^{\prime} 45.449^{\prime \prime} \mathrm{N}, 13^{\circ} 39^{\prime} 56.541^{\prime \prime} \mathrm{E}$ & 366 & 271 \\
\hline OS17 & SW of Osek & $50^{\circ} 36^{\prime} 29.138^{\prime \prime} \mathrm{N}, 13^{\circ} 40^{\prime} 49.935^{\prime \prime} \mathrm{E}$ & 140 & 133 \\
\hline ZL70 & $\mathrm{S}$ of Litvínov & $50^{\circ} 33^{\prime} 56.224^{\prime \prime} \mathrm{N}, 13^{\circ} 35^{\prime} 30.115^{\prime \prime} \mathrm{E}$ & 203 & 169 \\
\hline ZU5A & E of Teplice & $50^{\circ} 39^{\prime} 46.804^{\prime \prime} \mathrm{N}, 13^{\circ} 54^{\prime} 46.527^{\prime \prime} \mathrm{E}$ & 132 & 114 \\
\hline
\end{tabular}


Table 2. Clay mineral assemblage in the Most Basin sediments.

\begin{tabular}{llll}
\hline Member & Clay mineral assemblage & Diffraction pattern & Occurrence in drill cores \\
\hline Osek Mb. & R0, R1-rich & As Fig. 5A & OS17 \\
Lom Mb. & R0, R1-rich & As Fig. 5A & OS17, LK15 \\
Libkovice Mb. & R0, R1-rich & Fig. 5A & All drill cores \\
\hline & R1, K-rich & Fig. 5B & All cores below the Holešice/Libkovice boundary; \\
Holešice Mb. & R0, K-rich & As in Fig. 5A & AL505, DU7, HK930, LK15 in the entire Holešice Mb. \\
& $\begin{array}{l}\text { Mix of R0, R1-rich and } \\
\text { R1, K-rich }\end{array}$ & In-between Fig. 5A and 5B & LO565 and ZU5A above the Main Coal Seam \\
& & & \\
\hline
\end{tabular}

a trial-and-error procedure; the fundamental algorithm was developed by Drits \& Sakharov (1976) and Drits \& Tchoubar (1990).

The XRD patterns were used to analyse the clay mineral assemblages (Fig. 5). The sediments contain several populations of interstratified minerals, illite, and kaolinite (Tab. 2). The XRD patterns were fitted by two R1 (ordered stacking of layers, where $\mathrm{R}$ is the so-called Reichweite parameter) mixed-layer illite-smectite (-HI interlayer) phases, and two R0 (random stacking of layers) mixedlayer illite-smectite and kaolinite-smectite phases, with different distributions of coherent scattering domain sizes characterised by the mean value of layers $(\mathrm{N})$ according to Drits et al. (1997) and different ratios of expandable (smectite $-\mathrm{S} 2 \mathrm{~g}$ and $\mathrm{S} 1 \mathrm{~g}$ ) and non-expandable (illite, incomplete hydroxy interlayer) layers. Kaolinite was also fitted by two populations of crystallites with different coherent scattering domain sizes $(\mathrm{N})$, inherited kaolinite $\mathrm{N} 25-30$, and the end-product of weathered phyllosilicates, kaolinite $c a$. N6 or mixed-layer kaolinite-illite (85-95:15-5) R1, N15-20 (Viennet et al. 2015).

\section{Magnetic polarity analyses}

Magnetic polarity analyses were performed by incremental alternating field demagnetisation as described previously by Matys Grygar et al. (2014, 2017a, b). The demagnetisation included 10 to 15 demagnetisation steps using a 2G Enterprises 755R Cryogenic Magnetometer coupled with the 2G600 Automatic Sample Degaussing System (2G Enterprises, USA). The maximum demagnetisation step varied between 50 and $100 \mathrm{mT}$, according to the demagnetisation curves. Primary components were evaluated by principal component analysis using the Remasoft 3.0 software. The magnetic declination was not evaluated because the drill cores were not oriented. The samples from the Bílina Delta containing fine sand admixtures (MR93) were omitted. Individual samples with either magnetic inclination that was too low or opposite
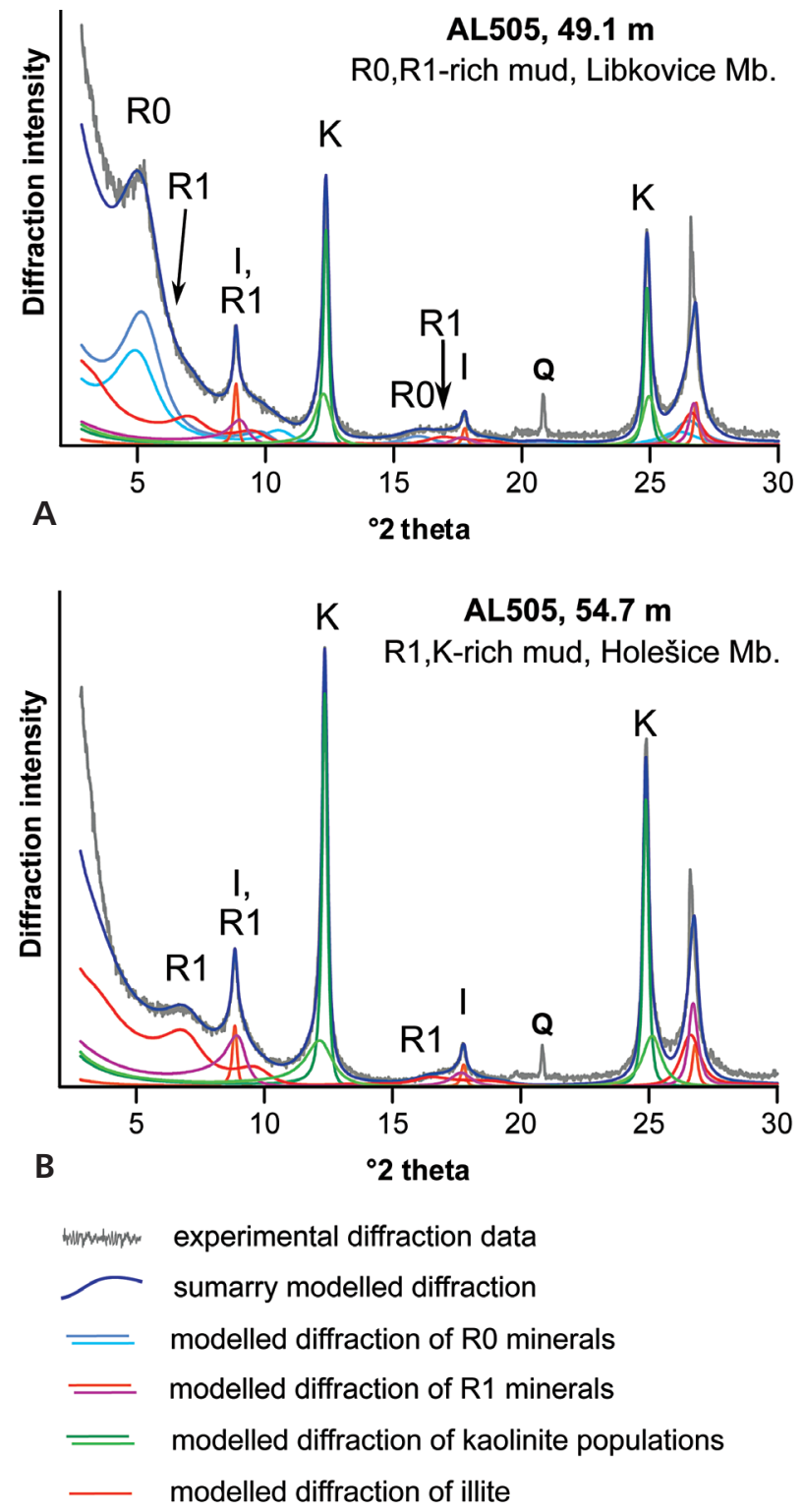

Figure 5. Typical diffraction patterns in Libkovice Member (A) and low-CEC Holešice Member (B) and their fitting by diffraction of individual clay minerals using the Sybilla software. 
orientation relative to their neighbours were disregarded from further evaluation, except for the samples from the magnetic reversals. The same assignment of retrieved magnetozones to polarity chrons was used as earlier (Matys Grygar et al. 2019a).

\section{Compositional data processing}

In this work, the use of geochemically normalised $\mathrm{K}$ and $\mathrm{Mg}$ concentrations as chemical weathering proxies was corroborated, as these can provide a robust record of the environmental changes in the sediment source area when they are corrected for lithological controls (Matys Grygar et al. 2019b). Normalised K concentrations are well-established weathering proxies (Garzanti et al. 2013, Matys Grygar et al. 2019b and references therein), while $\mathrm{Mg}$ concentrations have been used only sparsely (Dinis et al. 2017). Correction of $\mathrm{K}$ and $\mathrm{Mg}$ concentrations for sediment lithology is desirable in order to remove possible risk that the autocycles in fluvial and lacustrine systems, in particular distributary paths on the lake bottom and the lake hydrology itself, could contaminate the orbital signals in sediment composition via grain-size effects. The lithologically corrected weathering proxies potentially provide the most robust signals of the geochemistry of sediment sources in the lake catchment.

Because the sediment compositional data are closed, i.e. concentrations of all elements reflect contents of all constituents, including those which were not analysed (Pawlowsky-Glahn et al. 2015), processing appropriate log-ratios of element concentrations instead of working with raw concentrations must be preferred to avoid spurious correlations due to dilution effects (Van der Weijden 2002, Matys Grygar \& Popelka 2016). For alkali metal and alkali earth metal cations, geochemical normalisation by $\mathrm{Al}$ was justified in sediment analysis due to the similar grain-size distributions of both elements in mature sediments (Garzanti et al. 2013, Matys Grygar et al. 2019b). In the sediments of the Most Formation, element ratios like $\mathrm{K} / \mathrm{Al}$ (or $\mathrm{K} / \mathrm{Ti}$ in preceding works) represent $\mathrm{K}$ concentrations roughly corrected for the dilution by quartz, mostly in the silt size fraction, and siderite, the major autochthonous component present in the Most Basin clastics, in variable percentages.

The lithological effect on the weathering proxies was corrected by using the regression models applied to the (log-)ratio as a dependent variable. Because the geochemical datasets can be affected by the presence of some atypical values, conventionally called outliers, the regression coefficients were estimated robustly using the MM-algorithm of the RR (Yohai 1987, Koller \& Stahel 2011) instead of ordinary least-squares (LS) regression. At the side of regressors, the grain size was represented by the $\mathrm{Zr} / \mathrm{Rb}(\log )$ ratio and mineralogical effects were expressed by the isometric log-ratio (ilr)-transformed (Pawlowsky-Glahn et al. 2015) subset of elements Si, Fe, and $\mathrm{Ca}$. The performance of $\mathrm{Zr} / \mathrm{Rb}$ as a grain size proxy has already been documented in loess sequences (Chen et al. 2006) and verified in the Most Basin sediments by indirect proportionality with $\mathrm{Al} / \mathrm{Si}$ (Matys Grygar et al. 2019b). For further analysis of the orbital signal, residuals of the estimated robust regression models were used. The computations were done in the $\mathrm{R}$ software environment (R Core Team 2019). For the RR, the function lmrob from the package robustbase (Maechler et al. 2019) was employed.

\section{Local chemostratigraphy}

The local chemostratigraphic correlation scheme was taken from previous papers (Matys Grygar \& Mach 2013; Matys Grygar et al. 2014, 2017a, b, 2019a). Numbering of the K\# minima and crandallite beds $\mathrm{C \#}$ was taken from Matys Grygar \& Mach (2013) and Matys Grygar et al. (2017a); numbering is consecutive upward from the bottom of the clastic sediments above the Main Coal Seam (Figs 3, 4). The nature of the $\mathrm{K} \#$ minima was described in Matys Grygar et al. (2019b) and is attributed partly to chemical weathering maxima and partly to grain-size effects. Beds $\mathrm{C} 1$ to $\mathrm{C} 3$ are discernible in well-acquired drill cores as light-coloured layers of a few $\mathrm{cm}$ thick with crandallite, $(\mathrm{Ca}, \mathrm{Sr}) \mathrm{Al}_{3}\left(\mathrm{PO}_{4}\right)_{2}(\mathrm{OH})_{5} \cdot \mathrm{H}_{2} \mathrm{O}$. The $\mathrm{C} \#$ beds occur in known positions within the $\mathrm{K}$ chemostratigraphic curve, e.g. C2 is in the basal part of K5. Coarser particles, such as micas, silt-sized quartz, or mud microclasts, and $\mathrm{Zr} / \mathrm{Rb}$ maxima are associated with the $\mathrm{C} \#$ beds, which might indicate enhanced transport of coarser material to the lake centre.

\section{Cyclostratigraphy}

Spectral analyses were performed as described previously (Matys Grygar et al. 2017b). When necessary, the datasets were de-trended to ensure that the mean and the variance of the analysed signal were stationary. The spectral analyses were then performed using the multi-taper method (MTM) with three $2 \pi$-tapers (Thomson 1982, 1990). The confidence levels were calculated using the Mann \& Lees (1996) method, which was subsequently modified in Meyers (2014). Evolutive spectral analyses were performed using Fast Fourier Transforms (FFTs) on short intervals of the series, previously weighed by a Slepian sequence and stacked together to form a 3-D spectrum, namely a spectrogram (see Martinez et al. 2015). Two evolutive FFTs were carried out on windows of $100 \mathrm{~m}$ 
width to precisely document the smallest frequencies, and on windows of $40 \mathrm{~m}$ width to ensure the precise monitoring of the evolution of the highest frequencies through the interval analysed. Taner filters were then used to isolate frequency bands of interest in the spectra (Taner 2003).

\section{Results}

\section{Mineral composition}

Powder diffraction of whole-rock specimens identified quartz, kaolinite, mica-illite mixed layers, and kaolinite as major components, and $\mathrm{K}$-feldspar, mica-illite, and anatase as minor components. Quartz was mostly present as the silt grain size fraction. Siderite was present in variable percentages; $2-5 \%$ in average sediments and $10-35 \%$ in siderite laminae. In the Lom Member, minor amounts of pyrite were present. Pyrite particles could be in some cases observed by the naked eye.

The ratio between clay minerals was variable (Fig. 5), depending on the position of sediments in the basin and on the local stratigraphy (Fig. 6). The most prominent change in clay mineralogy was the switch from the R1,

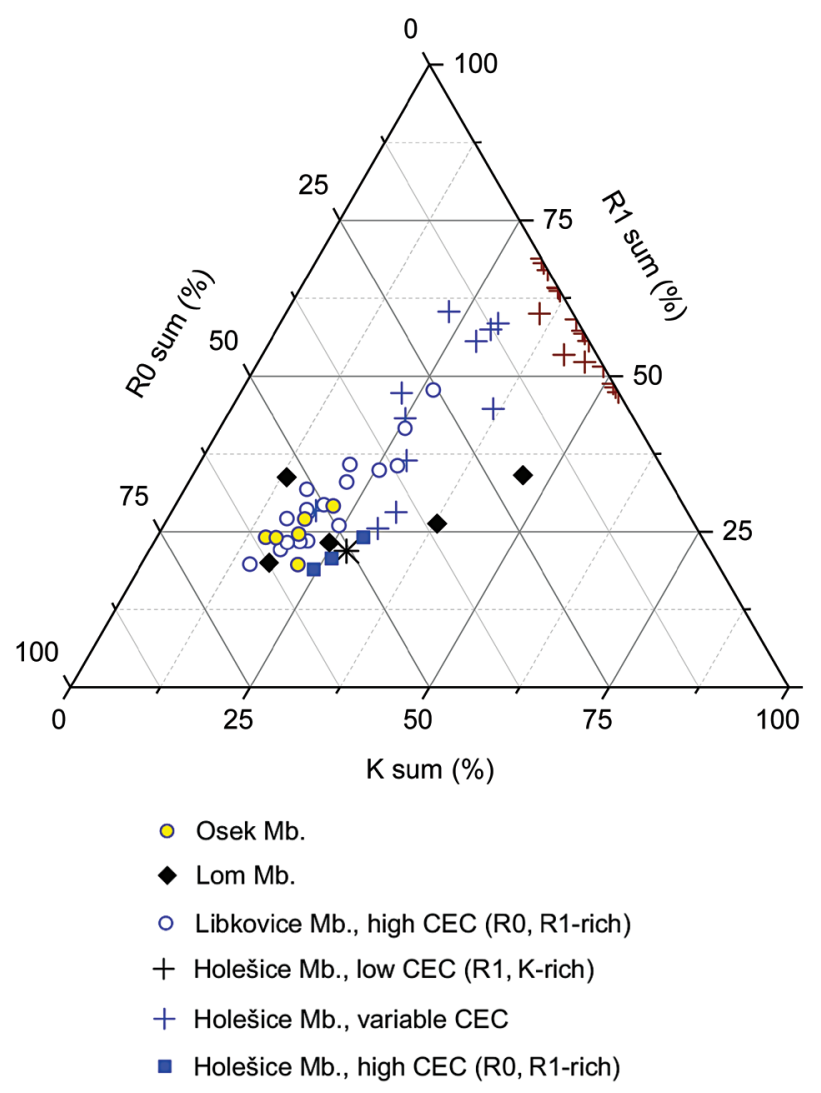

Figure 6. Relationships between clay mineral concentrations obtained by XRD analysis in the strata above the coal seam.
K-rich Holešice Member sediments to the R0, R1-rich Libkovice Member sediments (Tab. 2). This switch can also be visualised by the CEC step from $c a .0 .05 \mathrm{mmol}$ $\mathrm{Cu}^{2+} / \mathrm{g}$ to $c a .0 .1 \mathrm{mmol} \mathrm{Cu}^{2+} / \mathrm{g}$ or more in the Bílina Mine area (Fig. 4). This shift occurred nearly simultaneously with a magnetic polarity reversal and also with a K2 minimum (Fig. 7). The CEC step was traceable in all drill cores having coarser silty to fine sandy strata above the Main Coal Seam. The CEC step was less clear in several cores having only very fine sediments (with high $\mathrm{Al} / \mathrm{Si}$ ratios) and no sand admixtures just above the Coal Seam, such as in DU7, LK15, and ZL70. In LK15, the CEC step was rather weak, in ZL70 it was obscured by prestep local maxima, and in DU7 it was overlain by a poststep local minimum (Fig. 7). The association with the C5Dr/C5Dn magnetic polarity reversal documents that the major CEC step was isochronous, even in the case of local variability (DU7, LK15, and ZL70). The minor local variability (DU7, LK15, and ZL70) shows that the R0 structures were present in the basin already before the C5Dr/C5Dn reversal, but that they were either decayed or not deposited in the Bílina Delta and the proto-lake. The ultimate CEC step could be attributed to basin-wide slowing down of the lake flow-through regime.

\section{Magnetic polarity record and initial depth-age model}

Magnetic polarity analysis was performed on all new drill cores except LK15. The stack of overlapping cores covering all magnetic polarity zones, found above the Main Coal Seam, is shown in Fig. 8. The C5Dr.2r/C5Dr.1n reversal was found in the LB432 and JU2183 cores from the Bílina Mine area, i.e. from the Bílina Delta (the former is shown in Fig. 8). This confirms the previous conclusion that the Bílina Mine area was the site of the first protolake with clastic sediments formed inside the basin-wide swamp (Havelcová et al. 2013, Mach et al. 2014).

A subsequent reversal, C5Dr.1n/C5Dr.1r, was identified in new cores AL505, LB432, and MR93 and in previous work in DO565 and HK591 (Matys Grygar et al. 2019a). This reversal was not present in cores from the northern part of the basin (DU7, HK930, and ZL70). The upper interval of C5Dr.1n was also found in the hanging walls of the Bílina and Libouš mines above the Main Coal Seam (Matys Grygar et al. 2019a).

The C5Dr/C5Dn reversal was identified in all cores subjected to magnetic polarity analysis (Fig. 7). This reversal was associated with the CEC-step horizon at the Holešice/Libkovice boundary (Fig. 8).

Sediment strata with C5Dn/C5Cr and $\mathrm{C} 5 \mathrm{Cr} / \mathrm{C} 5 \mathrm{Cn} .3 \mathrm{n}$ reversals were preserved only in two of the newly analysed cores, HK930 and MR93, as these cores were obtained 


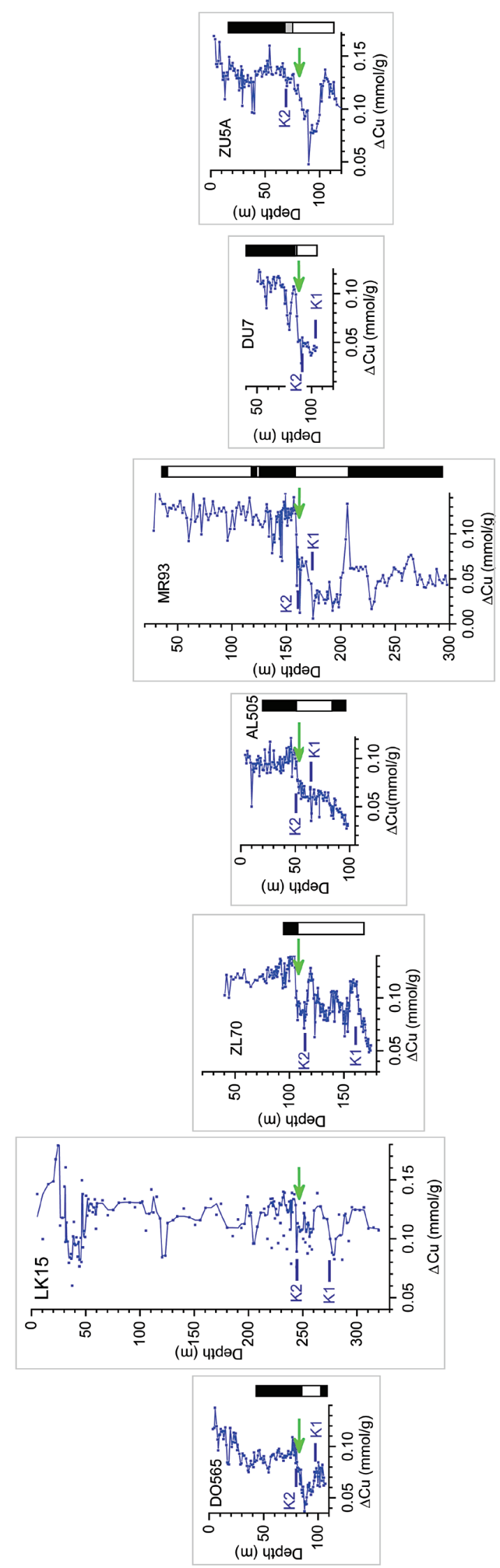

from near the centre of the basin, the area with the most extensively preserved strata of the Most Formation (Fig. 1). Other new cores were taken from areas wherein the younger strata had been eroded or are now too close to the land surface. The original magnetic polarity was not preserved down to a depth of 20-30 m, where the sediment usually shows signs of chemical weathering, such as a colour change from greyish to brownish shades. The entire polarity record available in the Miocene strata shown in Fig. 8 was completed with the previously reported OS17 core for the youngest sediments and with HK772 for the overlap between MR93 and OS17 (datasets for OS17 and HK772 cores were taken from Matys Grygar et al. 2019a).

The magnetic polarity analysis (e.g. Fig. 4A) produced the first estimates of the age models in the studied cores (Fig. 4B), as in Matys Grygar et al. (2019a). The uncertainties of the polarity time scales for the studied time intervals, as noted and discussed by Kochhann et al. (2016), Matys Grygar et al. (2017a), and Kasbohm $\&$ Schoene (2018), are larger than what is required to understand the MCO timing and course. Thus, the initial polarity-based depth-age model for the Most Basin was refined by orbital matching, as shown in Fig. 4C, D and as described below in more detail.

\section{Lithological correction of chemical weathering proxies}

Robust regression (RR) of the $\mathrm{K} / \mathrm{Al}$ and $\mathrm{Mg} / \mathrm{Al}$ ratios was performed using a grain size proxy ( $\mathrm{Zr} / \mathrm{Rb}$ ratio) and compositional variables (ilr function of $\mathrm{Si}, \mathrm{Fe}, \mathrm{Mg}$, and $\mathrm{Ca}$ for $\mathrm{K} / \mathrm{Al}$ and $\mathrm{Si}, \mathrm{Fe}$, and $\mathrm{Ca}$ for $\mathrm{Mg} / \mathrm{Al}$ ) as explanatory (independent) variables (Tab. 3). The RR performance is demonstrated in Fig. 9A-D, where weight ratios of $\mathrm{Mg} / \mathrm{Al}$ and its robust regression residuals (RRes) are plotted against concentrations of carbonate-forming elements $\mathrm{Ca}$ and $\mathrm{Fe}$, showing that the RRes are not dependent on the carbonate content. Siderite is the major diagenetic mineral component in the Most Basin sediments. It is present in highly variable percentages and contains certain amounts of $\mathrm{Mg}$ and $\mathrm{Ca}$.

Lithological corrections only slightly changed the depth profile of the raw $\mathrm{K} / \mathrm{Al}$ weight ratio used for local stratigraphy (Fig. 9E). For Mg/Al, RRes corrections to the depth profiles considerably suppressed the influence of the siderite- or calcium-carbonate-associated single-point maxima (red asterisks in Fig. 9E), which were particularly frequent in the Holešice Member in MR93, as carbonates occurred in strata with thicknesses of a few $\mathrm{cm}$ to a few $\mathrm{dm}$.

Figure 7. Lateral correlation of the CEC step and magnetic polarity reversal C5Dr/C5Dn in the Holešice/Libkovice boundary. 


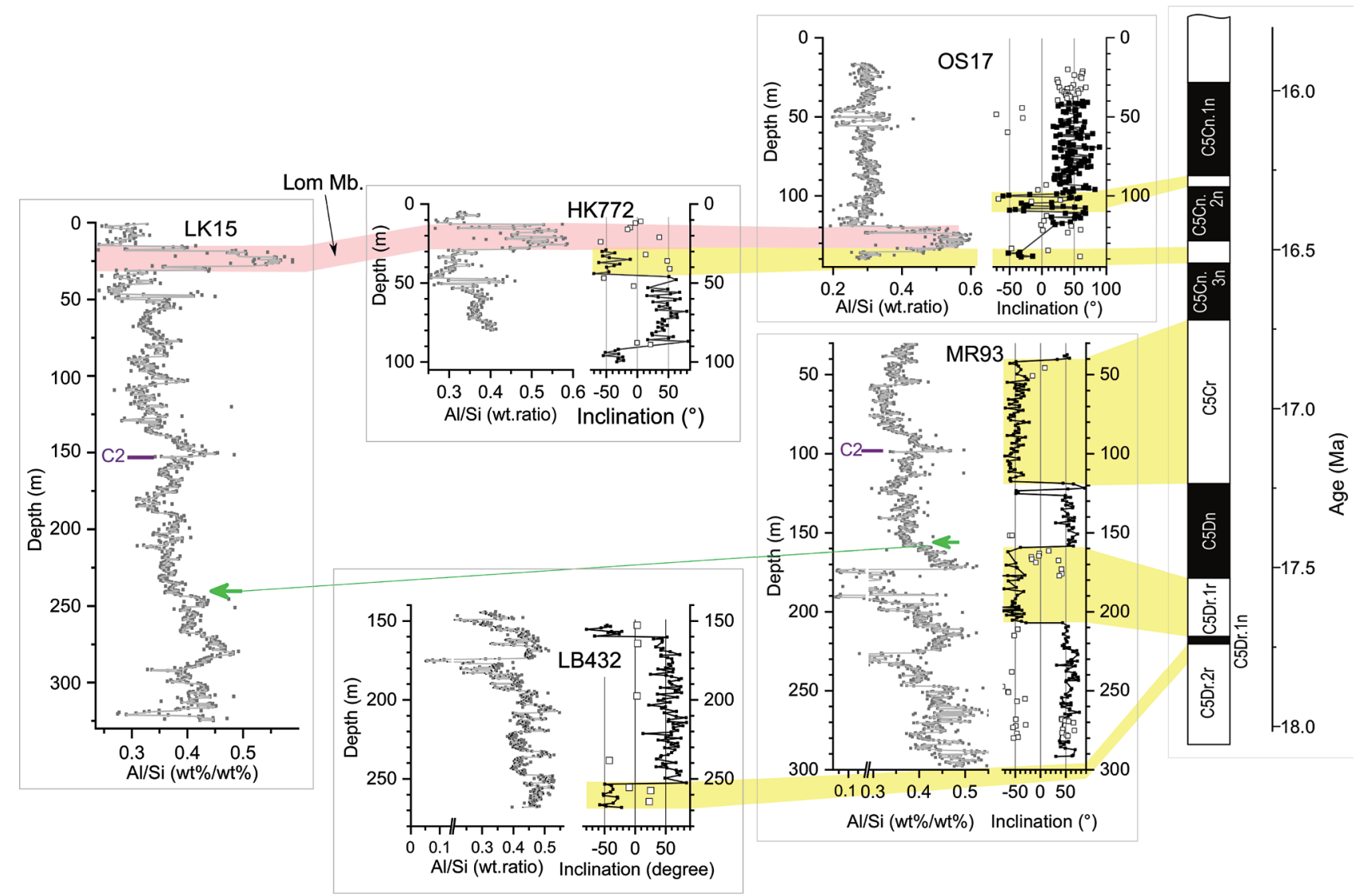

Figure 8. Correlation scheme for the Most Basin with the most important new cores (LB432, LK15 and MR93) and previously analysed cores (OS17 and HK772) taken from Matys Grygar et al. (2019a).

\section{Spectral analysis and orbitally matched depth-age model}

MTM spectra of LK15 and MR93 drill cores are shown in Fig. 10. The assignments of the wavelengths to orbital cycles is consistent both with the sedimentation rate from the magnetic polarity-based depth-age model for MR93 and with previously published spectral analyses. Spectrograms applied to the K/Al ratio in the MR93 core (Fig. 11) show different powers of individual orbital cycles in distinct stratigraphic depths. All cores from the Most Basin showed a dominance of short eccentricity, usually with precession modulation in eccentricity maxima, in the $\mathrm{K} / \mathrm{Al}$ (or $\mathrm{K} / \mathrm{Ti}$ ) depth profiles in the chemostratigraphic interval from K1 to K5 (Fig. 4). This is replaced by a dominance of obliquity between $\mathrm{K} 5$ and $\mathrm{P} 1$ around the low-eccentricity cycle centred near 17.0 Ma. Finally, the precession signal dominates in the P1 interval (Fig. 4). In the $\mathrm{Mg} / \mathrm{Al}$ RRes, eccentricity is weaker (Fig. 10A) or absent (Fig. 10B), but similarly as for K/Al, obliquity and precession signals were found. The important result to highlight is that both the raw and the lithologically corrected $\mathrm{K} / \mathrm{Al}$ and $\mathrm{Mg} / \mathrm{Al}$ ratios, i.e. their RRes, allowed identification of very similar or equal frequencies in their spectra.

All these features were used in the manual orbital tuning of the initial magnetic polarity-based depth-age models for individual cores; an example is shown in Fig. 4 for MR93. The stack of K/Al depth profiles of drill cores dated in this manner is shown in Fig. 12. The model for LK15

Table 3. Variables for robust regression of element ratios; $\mathrm{g}()$ represents the geometrical mean for variables in parentheses.

\begin{tabular}{l|l}
\hline Response (dependent) variable & Explanatory (independent) variable \\
\hline $\log (\mathrm{K} / \mathrm{Al})$ & $\log (\mathrm{Zr} / \mathrm{Rb}), \log (\mathrm{Si} / \mathrm{g}(\mathrm{Fe}, \mathrm{Ca}, \mathrm{Mg})), \log (\mathrm{Fe} / \mathrm{g}(\mathrm{Ca}, \mathrm{Mg})), \log (\mathrm{Ca} / \mathrm{Mg})$ \\
$\log (\mathrm{Mg} / \mathrm{Al})$ & $\log (\mathrm{Zr} / \mathrm{Rb}), \log (\mathrm{Si} / \mathrm{g}(\mathrm{Fe}, \mathrm{Ca})), \log (\mathrm{Fe} / \mathrm{Ca})$
\end{tabular}


A

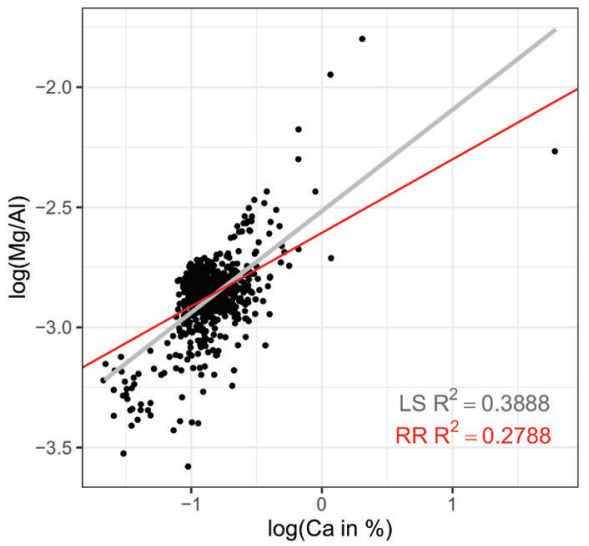

C

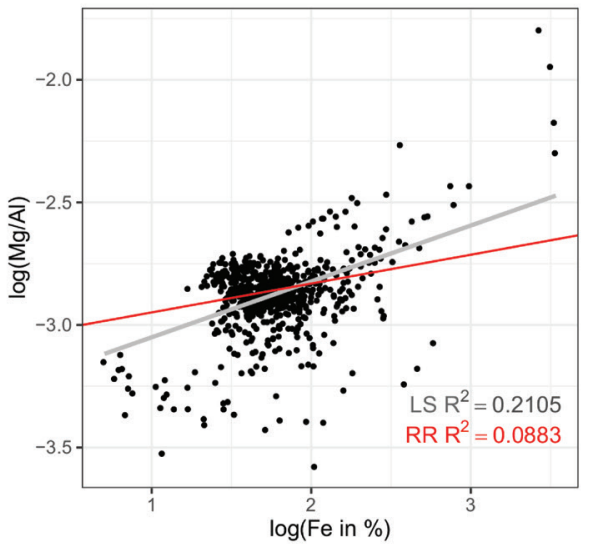

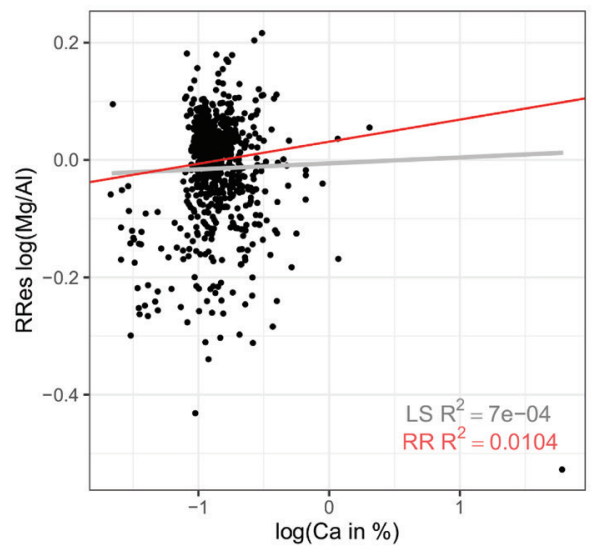

B

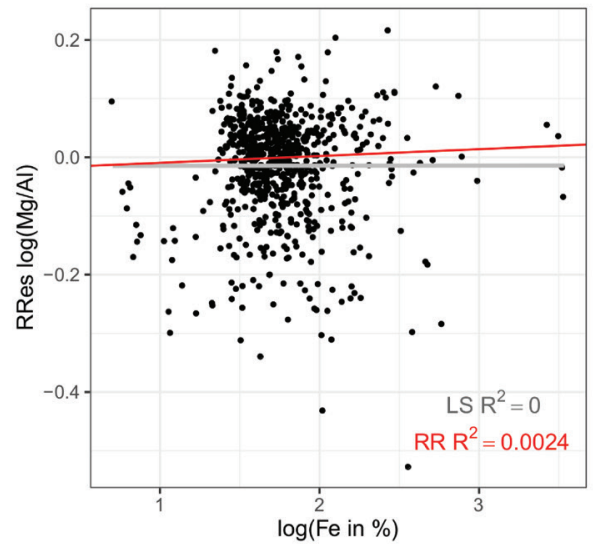

D

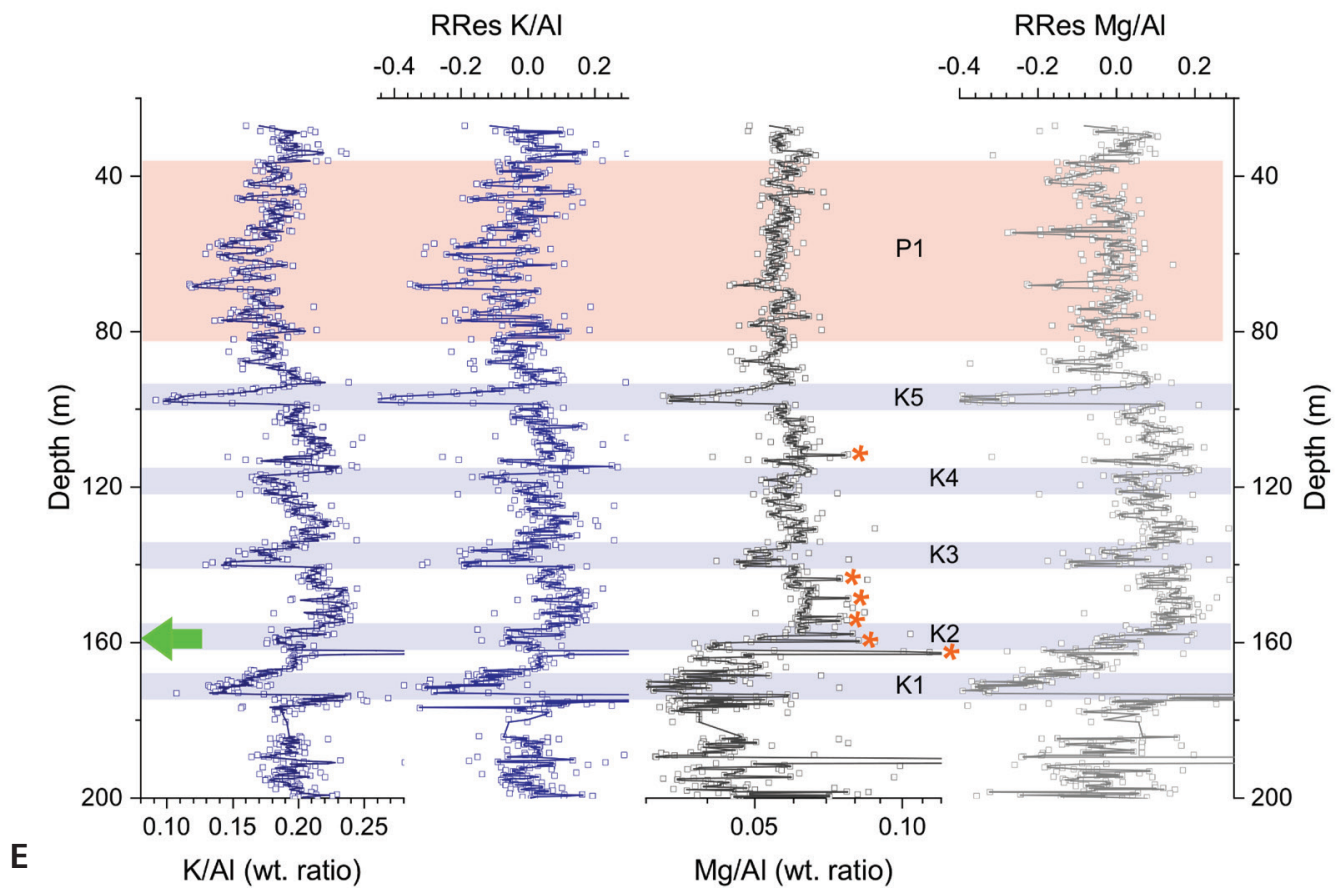

Figure 9. Lithological correction of $\mathrm{Mg} / \mathrm{Al}$ ratio by robust regression of log-ratios demonstrated for $\mathrm{MR} 93$ core. $\mathrm{Mg} / \mathrm{Al} v s . \mathrm{Ca}(\mathrm{A})$ and $\mathrm{Fe}(\mathrm{C})$ and $\mathrm{Mg} / \mathrm{Al} \mathrm{RRes} v s$. Ca (B) and Fe (D). Correlation by ordinary (LS) regression is in grey, RR is in red. Lithological correction removes correlation of $\mathrm{Mg} / \mathrm{Al}$ with concentrations of the carbonate-forming elements. Stack with raw $\mathrm{K} / \mathrm{Al}$ and $\mathrm{Mg} / \mathrm{Al}$ and their robust residuals RR (E). Red asterisks show carbonate beds in raw $\mathrm{Mg} / \mathrm{Al}$, effects of which are suppressed in RRes. 

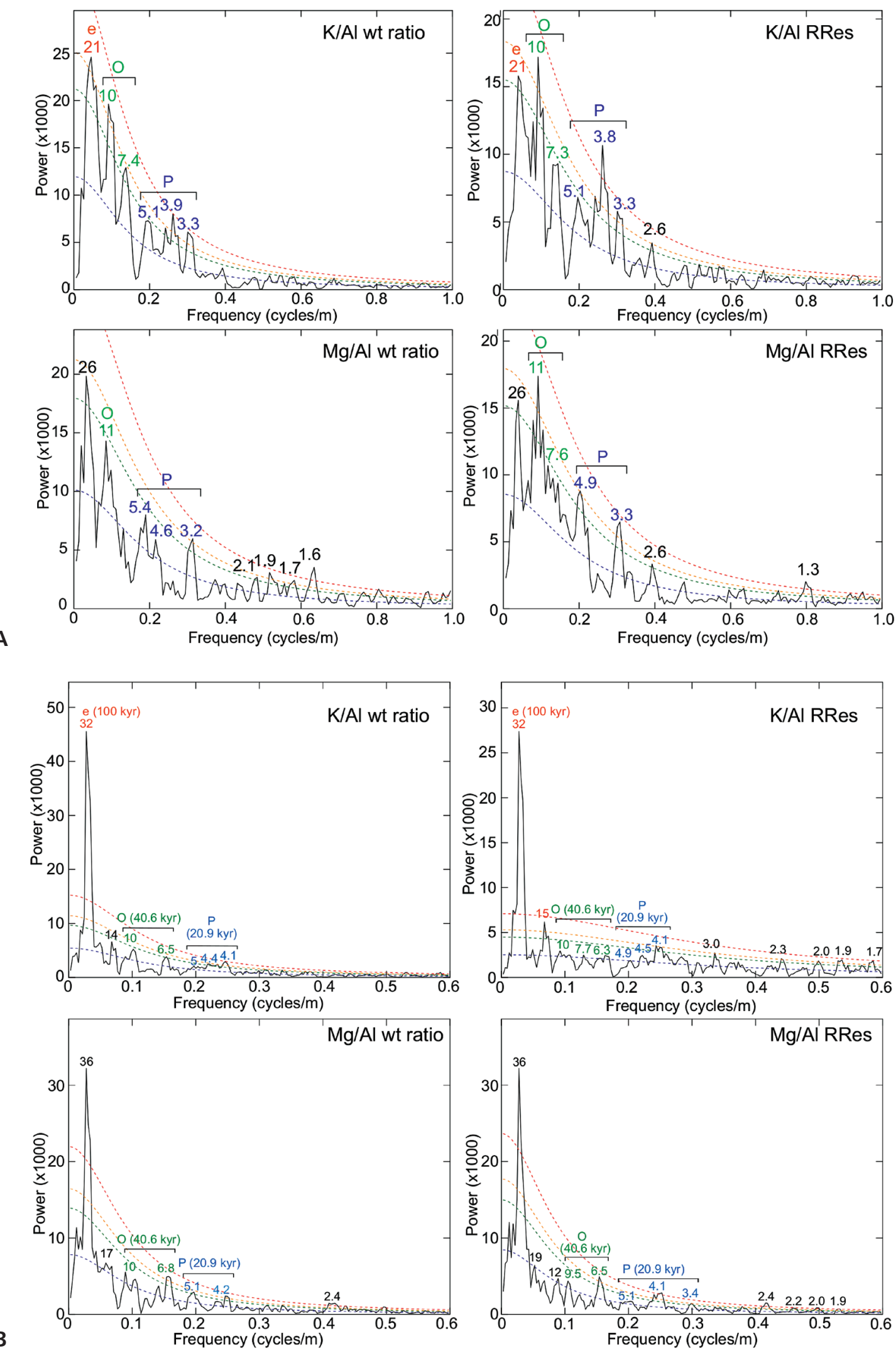

Figure 10. MTM spectra of chemical weathering proxies in MR93 (A) and LK15 (B) cores. The numbers in spectral peaks are wavelengths of cycles in metres. 


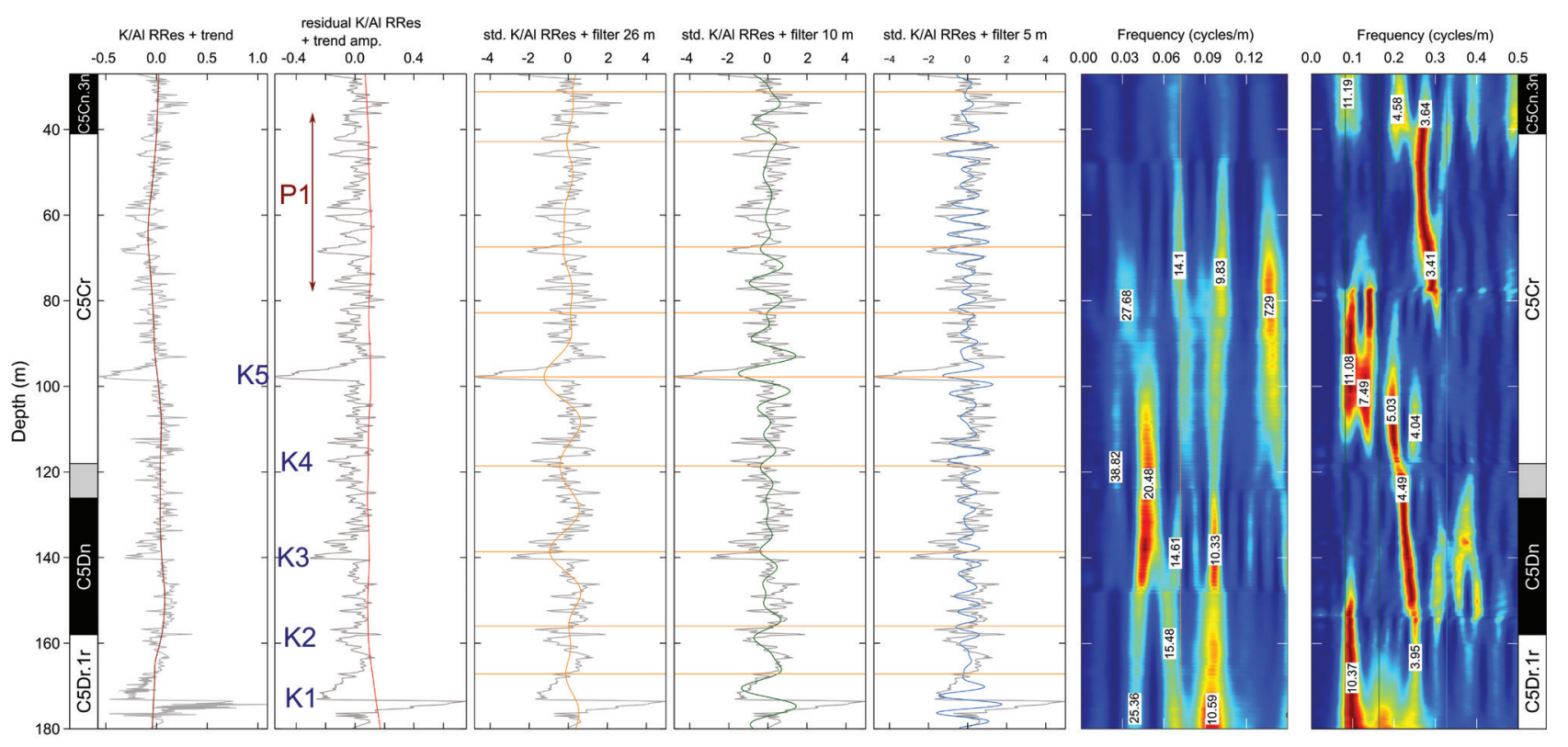

Figure 11. Evolutive spectra of $\mathrm{K} / \mathrm{Al}$ in MR93 drill core.

was derived chemostratigraphically from MR93, and by orbital matching analogously to the derivation in other cores with the magnetic polarity-based initial age model. The very low-eccentricity cycles centred at $17.392 \mathrm{Ma}$ (between K2 and K3) and 17.092 Ma (between K5 and $\mathrm{P} 1)$ were mostly not recognised in weathering proxies. $\mathrm{K} 1$ to K4 were matched to eccentricity maxima (Fig. 4) according to the astronomical solution La04 (Laskar et al. 2004) as described by Matys Grygar et al. (2019a). The P1 interval (Fig. 4) was recognised as a series of 11-12 precession cycles (wavelength 3-5 $\mathrm{m}$ ) discernible in the $\mathrm{K} / \mathrm{Al}$ depth profiles and attributed to the 3 succeeding higheccentricity cycles in the period of 16.95-16.69 Ma in the astronomical solution (Fig. 4). The sedimentation rates in the Libkovice Member sediments were comparable to previous findings in other cores, and ranged from 15 to $25 \mathrm{~cm} / \mathrm{kyr}$, or exceptionally between $10-15 \mathrm{~cm} / \mathrm{kyr}$ in some parts of MR93 and between $25-30 \mathrm{~cm} / \mathrm{kyr}$ in the lower part of LK15.

The precision of the age model may be evaluated from the misfits in $\mathrm{K}$ minima in individual cores shown in Fig. 12. Here, the yellow lines indicate rough positions of the local minima (controlled by orbital precession at wavelengths of 3-5 m; Fig. 10) and documents consequences of non-linear response of weathering proxies to orbital forcing, which complicates the selection of the eccentricity-controlled minimum. The second source of the misfit may be the polynomial fit in the depth-age model together with variable deposition rates in the cores. Nonetheless, the precision within a single precession cycle is extraordinarily high for the Miocene sedimentary records.

\section{Discussion}

\section{Performance of weathering indices and their spectral analyses}

All previously used weathering proxies showed grainsize control. Finer sediment particles, usually secondary minerals formed in the weathering crust, are inevitably more chemically mature than coarser particles, which may include primary minerals or even physically weathered rock grains (Garzanti et al. 2013, Tanaka \& Watanabe 2015). To treat this issue, we introduced RR corrections of the chemical compositions of sediments for the grainsize variability and variable content of autochthonous components. This correction did not weaken orbital signatures found in the raw $\mathrm{K} / \mathrm{Al}$ and $\mathrm{Mg} / \mathrm{Al}$ ratios (Fig. 10) that support their assignment to climatic signals. The weathering proxies also produced laterally continuous records in the basin fill (Fig. 12 shows this for K/Al), which further support their attribution to the external control.

Noteworthy is a variable power of individual orbital frequencies in $\mathrm{K} / \mathrm{Al}$ and $\mathrm{Mg} / \mathrm{Al}$ depth profiles (Fig. 10), which show that they are not just 'copies' of the same mineralogical pattern. Each of these elements has specific relations to the mineralogical transformations that occur in weathering: $\mathrm{K}$ is liberated from feldspars and micas and later by ion-exchange and transformations of clay minerals; $\mathrm{Mg}$ is liberated from micas, chlorites, and carbonates after their dissolution. Interestingly, the K/Al ratio bears a dominant signal of eccentricity, which is in fact missing in that of $\mathrm{Mg} / \mathrm{Al}$; the cycle found in the 
Figure 12. Stack of K/Al depth profiles in individual drill cores. The age models were obtained by magnetic polarity age model refined by orbital matching shown in Fig. 3, the model for LK15 was obtained by lateral correlation with MR93 and orbital matching. Light blue polygons mark $\mathrm{K} 1$ to K5 minima, yellow vertical lines in $\mathrm{K} 3$ shows precession-controlled modulation of the $\mathrm{K}$ minima, light red polygon marks precessioncontrolled period P1 (Fig. 3).

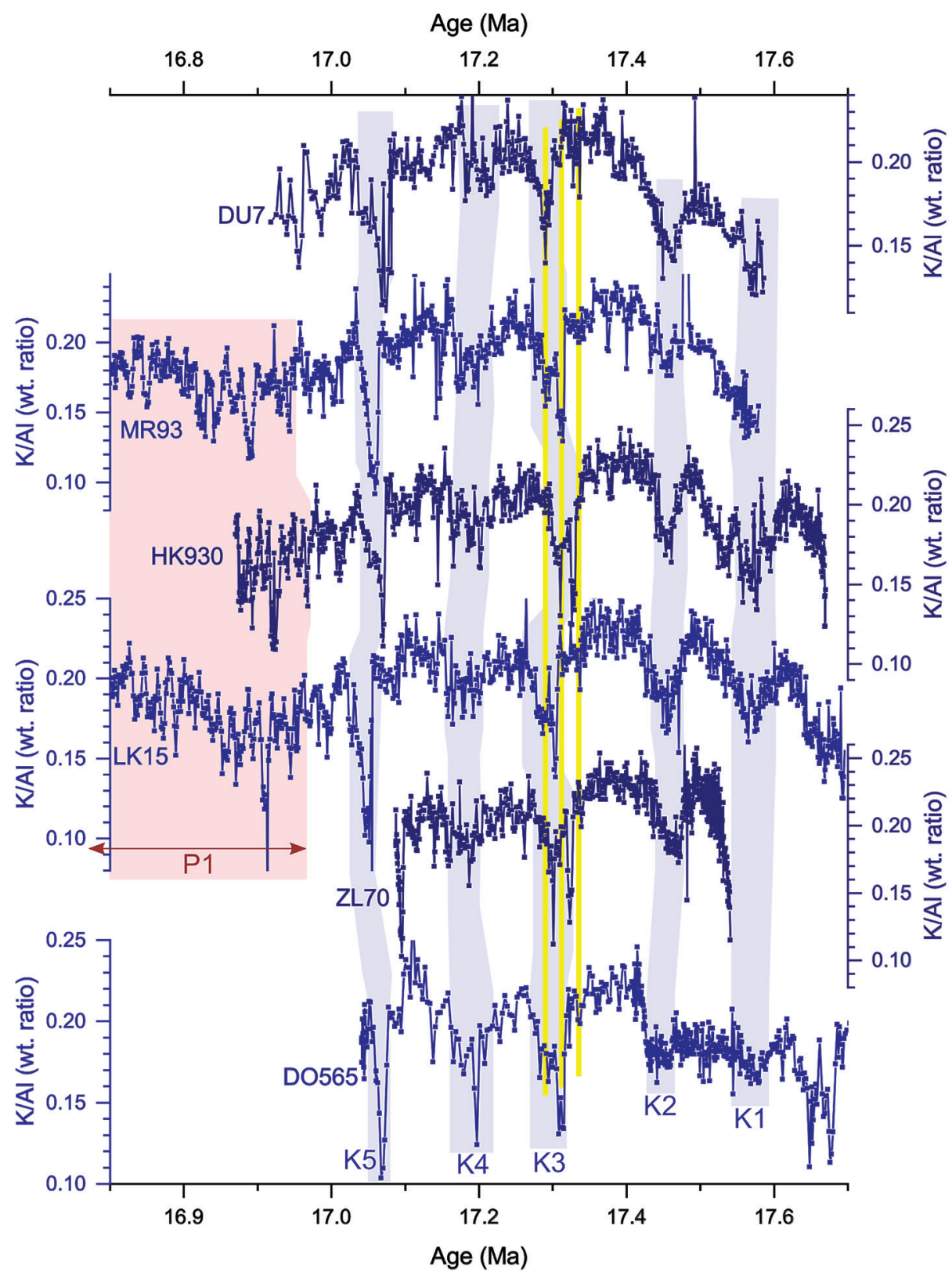

latter at $c a .36 \mathrm{~m}$ is too long to be assigned to the short eccentricity.

The detailed spectral analyses of weathering proxies in the Most Basin, the results of which cannot be shown in the limited space of this paper, revealed two challenges for cyclostratigraphy in the studied sediments. First, variable initial deposition rate in the Most Basin caused by spatially variable compaction of peat underlying the lacustrine clastic deposits, as discussed above, hindered the use of evolutive spectra for the LK15 core (not shown). Surprisingly, the output of this method was not improved after replacing the analysis in depth scale with that in temporal scale using an orbitally matched depth-age model for LK15. We assigned this failure to the variable amplitude of precession and eccentricity signals in individual cores, which can be inferred from the sitespecific expression of individual $\mathrm{K}$ minima $\mathrm{K} 1$ to $\mathrm{K} 5$ in Fig. 12. For example, $\mathrm{K} 1$ is relatively weak in MR93 and DO565, while K4 is poorly discernible in DU7 and LK15, and similar variability in amplitude can be shown in precession modulation of the $\mathrm{K}$ minima. This nonlinearity can be attributed to the complexity of climate recording mechanisms inherent to continental basins, and conclude that lateral stability of orbital signals must be checked as part of their study, using spectral analyses of more cores before making definitive evaluations of orbital imprints. Indeed, the MR93 core produced one of the most robust results obtained to date in the Most Basin. 


\section{Most Basin evolution}

The Bílina Delta was formed during the end of C5Dr.2r and developed mainly during the C5Dr.1n subchron (cores LB432 and JU2183). The lake body was originally surrounded by the peat swamp and slowly expanded by flooding the swamp edges and burying the bases of tree stumps (Mach et al. 2013, Havelcová et al. 2013). The sedimentation rate in the prodelta of the Bílina proto-lake in the LB 432 core would be $c a .220 \mathrm{~cm} / \mathrm{kyr}$ and $400 \mathrm{~cm} / \mathrm{kyr}$ according to the duration of CDr.1n in polarity timescale ATNTS2012 (Hilgen et al. 2012) and the timescale reported by Kochhann et al. (2016), respectively. The huge accumulation of Bílina Delta deposits during CDr.1n was confirmed in MR93 (Fig. 8). We attributed such fast deposition to the limited spatial extent of the Bílina Delta relative to the area of the entire basin floor. Later, the sediments brought to the basin by the Bílina river were spread over an area more than an order of magnitude larger, and the mean vertical deposition rate decreased correspondingly. The accommodation space for the thick deposits of the Bílina Delta was probably formed via the compaction of the underlying peat strata. During the subchron C5Dr.1n, which lasted 20-40 kyr (Hilgen et al. 2012, Kochhann et al. 2016), clastic deposits were also collected by several isolated lakes located in the opposite side of the graben, in the Most Area (AL505) and in the Libouš Mine area (DO565). Because this subchron was not found in ZL70 and HK930 drill cores, nor further to the north (DU7), it is inferred that the northern part of the basin was flooded later than its centre. The basin-wide lake was thus formed early in the C5Dr.1r chron.

Substantial changes occurred in the Holešice/Libkovice boundary near the C5Dr/C5Dn reversal at $c a$. 17.47 Ma (Kochhann et al. 2016, Matys Grygar et al. 2019a) and the K2 minimum assigned to the eccentricity maximum at $c a$. $17.46 \mathrm{Ma}$ (Laskar et al. 2004). The major change in the Most Basin sediments was the change in the clay mineral assemblage, in particular an increase in the fraction of I/S R0 or its first appearance in sediments (Tab. 2), which can also be visualised as the CEC step, with $\Delta \mathrm{Cu}$ growing from $c a .0 .05$ in the Holešice Member to more than $0.1 \mathrm{mmol} \mathrm{Cu}^{2+} / \mathrm{g}$ in the Libkovice Member (Matys Grygar et al. 2014, 2017a). The more representative coverage of the basin floor provided by drill cores now permitted identification of certain site specificity of this transition; the CEC was nearly $0.1 \mathrm{mmol} \mathrm{Cu} / \mathrm{g}$ and I/S R0 minerals were present already in the Holešice Member in cores LK15 and ZL70 (Fig. 7), where the $\Delta$ Cu step was from $c a$. 0.11 to $c a .0 .13 \mathrm{mmol} \mathrm{Cu}^{2+} / \mathrm{g}$ and 0.09 to 0.14 $\mathrm{mmol} \mathrm{Cu}{ }^{2+} / \mathrm{g}$, respectively. We previously proposed three possible explanations for the clay mineralogical change behind the CEC step in the Holešice/Libkovice boundary: a change in the hydrological regime in the Most Basin with smectite rich (finest) clay minerals deposited only under calm flow regimes of the Libkovice lake; a basin-wide change in lake water chemistry; or a basin-wide change in the catchment geochemistry/clay mineralogy. The site-specific features of the CEC step are consistent only with the first explanation. The hydrological regime could have changed due to either climate or tectonics; however, it is important to note the coincidence of the polarity reversals and the eccentricity-triggered $\mathrm{K}$ minimum. The association of possible tectonic triggers with chemical weathering minima may revoke the association between volcanic activity and orbital cycles mainly that of short eccentricity reported recently for the Pleistocene records (Schindlbeck et al. 2018, Kutterolf et al. 2019). However, even if the coincidence of the polarity reversal and the CEC step could have resulted from a short-term hiatus, it would probably indicate tectonic activity in an otherwise continuous sedimentary record, i.e. an abrupt change in the basin development. However, the sediment profiles did not show conventional signs of hiatuses, such as poorly correlated strata with erosional surfaces.

The sediments of the Libkovice Member were deposited for $c a$. 1.0 Myr during C5Dn, C5Cr, and C5Cn.3n chrons, when the depositional environment was stable, as can be inferred from their uniform appearance and lithology. The sediment geochemistry shows laterally correlated (Fig. 12), orbitally controlled variability (Figs $4,10,11)$. An abrupt change in the sediment geochemistry patterns occurred near 17.0 Ma; the weathering indices showed step-like decreases and the frequencies of their cycles increased due to the change from domination by eccentricity to domination by precession and obliquity (Fig. 11), which were previously attributed (Matys Grygar et al. 2017b, 2019a) to global change at the onset of the MCO according to work by Holbourn et al. (2015) and Kochhann et al. (2016). These changes are discussed in more details below.

The 'high-frequency' geochemical variability (expression of orbital precession, in particular in the P1 interval) in the $\mathrm{C} 5 \mathrm{Dn}$ and $\mathrm{C} 5 \mathrm{Cr}$ chrons disappeared near the $\mathrm{C} 5 \mathrm{Cr} / \mathrm{C} 5 \mathrm{Cn}$ boundary, above which orbital forcing became unclear (Figs 4,11). The composition of younger sediments then shows several abrupt, laterally correlated changes: step-like coarsening followed by the onset of the Lom Member with coaly, illite-rich clays and thin coal beds deposited between 16.52 and 16.37 Ma (LK15 core). The lake did not desiccate in this period; the Lom Member coal beds are saprolitic, with a considerable proportion of organic matter of aquatic origin (Havelcová et al. 2015). Interestingly, the clay mineralogy in the Lom Member sediments is not much different with respect to that of the Libkovice and Osek members (Fig. 6). In the Lom Member sediments, geomagnetic polarity was not measurable, probably due to destruction of the original 

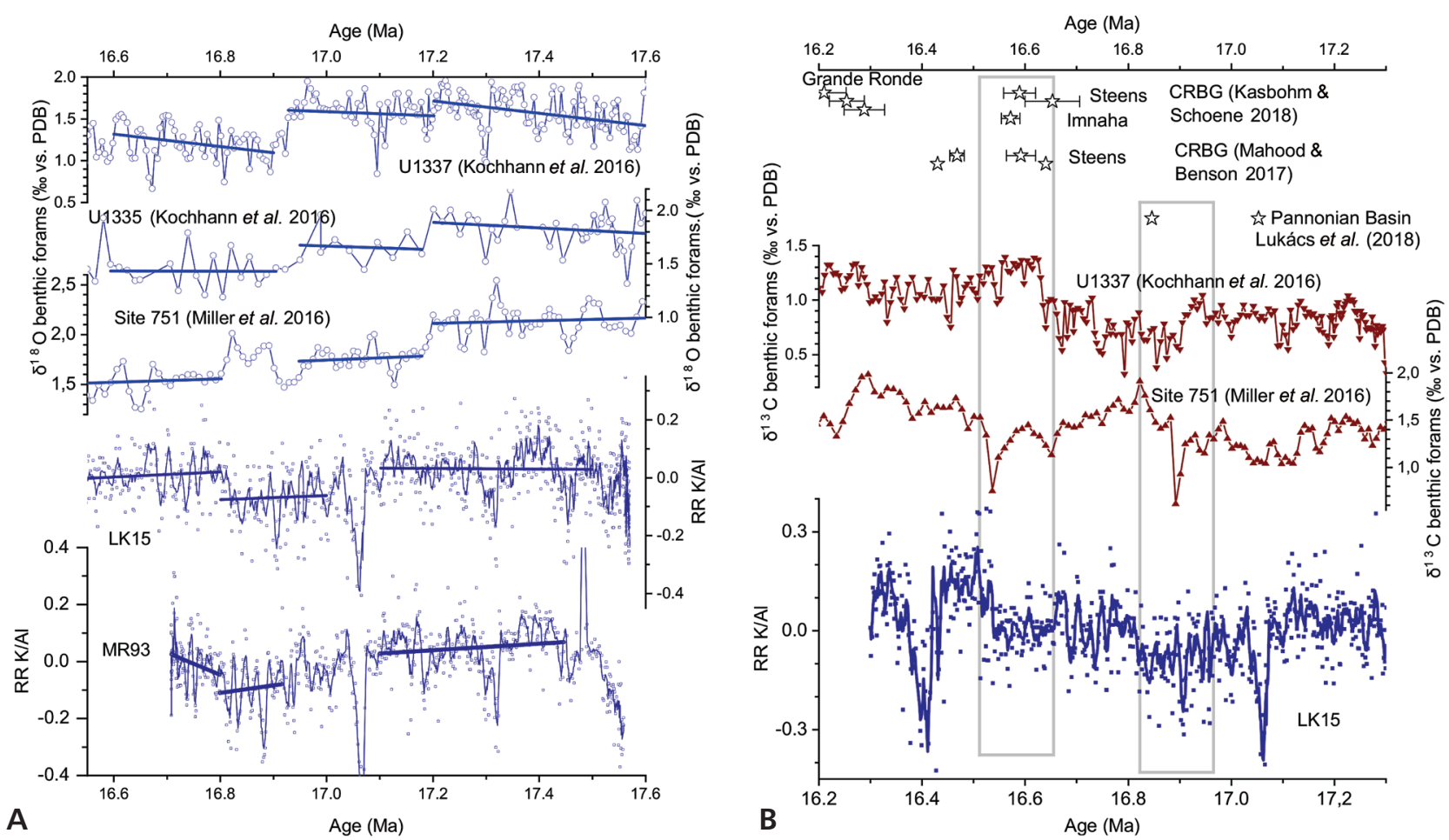

Figure 13. The Most Basin record of the weathering intensity compared with marine isotopic records and major volcanic eruptions (asterisks in panel B).

magnetic carriers by abundant organic matter. The $\mathrm{C} 5 \mathrm{Cn} .2 \mathrm{r} / \mathrm{C} 5 \mathrm{Cn} .2 \mathrm{n}$ reversal was thus not recovered, and most of $\mathrm{C} 5 \mathrm{Cn} .2 \mathrm{n}$ was missing from the Most Basin record (Fig. 8; see also Matys Grygar et al. 2019a).

The abrupt changes in the Most Basin sediment geochemistry could be attributed to tectonic or climatic changes. The Most Basin was over-filled sensu Carroll \& Bohacs (1999) and we thus assume that climate controlled the influx of clastic sediments and residence time of water in the lake rather than the overall water level. The lake level would then mirror tectonic development of the basin. No way is known to distinguish unequivocally between climatic and tectonic controls over the catchment weathering, erosion balance, and fluvial networks, which could subsequently impact lake sediment geochemistry. We do, however, assume that tectonics would preferentially change the sediment lithology, and we thus introduced the lithological corrections to the weathering indices. We will hereafter focus on the patterns of orbital controls in the sediment geochemistry and compare their abrupt changes with global climate records in an aim to separate the Most Basin climatic record.

\section{Comparison of Most Basin and marine records}

Comparison of the Most Basin findings with marine records is hindered by the lower temporal resolution of the latter (Fig. 13), misfits of the existing magnetic polarity time scales (discussed in Kochhann et al. 2016, Matys Grygar et al. 2019a, and Kasbohm \& Schoene 2018), several dating and tuning strategies utilised in marine records (Beddow et al. 2018), and possible hiatuses in marine sediments around $17 \mathrm{Ma}$ (Wu et al. 2014, Miller et al. 2017) or before the MCO onset. In spite of these hindrances, we have already found associations of the Most Basin record with global events, in particular the temporal co-incidence of the Bílina Delta expansion to the basin-wide lake with the AIS reduction and the change in the orbital patterns in the stable lacustrine deposits near 17.0 Ma with the onset of the MCO (Matys Grygar et al. 2017b). These and other phenomena are discussed hereafter in more detail due to progress in the study of both the Most Basin (this work) and global records (Miller et al. 2017) and events (Kasbohm \& Schoene 2018).

Figure 13 shows the K/Al RRes plot for the LK15 core and the two most-detailed marine $\delta^{18} \mathrm{O}$ and $\delta^{13} \mathrm{C}$ records available for the same period of time (Kochhann et al. 2016, Miller et al. 2017). All records show temporal coincidence of abrupt changes in mean weathering intensity and their orbital signatures and step-like changes in marine $\delta^{18} \mathrm{O}$ records with two steps centred at $c a .17 .1$ and 16.9 Ma. Nearly coeval with these shifts were two of four erputions of silicic volcanism in the Pannonian Basin, the largest events of that kind in the European scale in the 
middle Miocene, dated to 17.06 and 16.82 Ma by Lukács et al. (2018). The steps in marine $\delta^{18} \mathrm{O}$ were in the focus of Kochhann et al. (2016) and Miller et al. (2017) as possible formal starting points of the MCO. These two $\delta^{18} \mathrm{O}$ shifts were also accompanied by enhanced carbonate dissolution due to carbon cycle disturbance (Wu et al. 2014, Kochhann et al. 2016, Miller et al. 2017); around 16.9 Ma, the marine $\delta^{13} \mathrm{C}$ curves show abrupt shifts (Fig. 13). As described above, we found substantial changes in the sediment geochemistry and its orbital signatures in the Most Basin between $c a$. 17.1 and 16.9 Ma; specifically, an abrupt increase in the intensity of chemical weathering in both the raw and lithologically corrected weathering indices, and a switch of orbital sensitivity of the Most Basin geochemistry from eccentricity control (interval from $\mathrm{K} 1$ to K5) to obliquity (above K5) and precession (in P1 interval) controls (Figs 4, 9E, 12, 13). The timing of these steps is nearly coeval with the estimates of the onset of the MCO by Kochhann et al. (2016) and Miller et al. (2017) (Fig. 13), and we thus interrelated these events.

It is noteworthy that $\mathrm{K} 5$, the most prominent chemical weathering minimum in the entire Most Basin with the major crandallite bed $\mathrm{C} 2$ (Fig. 4), actually lies between the shifts in marine $\delta^{18} \mathrm{O}$. We assigned these abrupt shifts and markers to a series of global environmental disruptions, triggers of which have not yet been identified. The general similarity between the $\delta^{18} \mathrm{O}$ records and the Most Basin weathering proxies shown in Fig. 13 is in contradiction with the conclusion by Miller et al. (2017) that there are hiatuses in the records of Holbourn et al. (2015) and Kochhann et al. (2016). It is, however, possible that the abrupt shifts occurred in geographically specific ways and at various parts of the Atlantic and Pacific oceans.

A further abrupt shift in the weathering proxies of the Most Basin can be identified between 16.65 and 16.6 Ma. Holbourn et al. (2015) and Kochhann et al. (2016) denoted the $\delta^{13} \mathrm{C}$ shift at $c a .16 .63 \mathrm{Ma}$ as the onset of the Monterey Carbon Isotope Excursion, i.e. some disruption of the global carbon cycle. Practically coeval with this shift was the start of the youngest (Steens) basalt flood of the Columbia River Basalt Group (CRBG, Mahood \& Benson 2017, Kasbohm \& Schoene 2018). The precise dating of the CRBG floods has developed considerably in the last decade (Barry et al. 2010, Mahood \& Benson 2017, Kasbohm \& Schoene 2018, and references therein), but the coevality of these events is also confirmed by magnetic polarity reversals; both the marine $\delta^{13} \mathrm{C}$ break (Kochhann et al. 2016) and the onset of the Steens basal flood occurred near the $\mathrm{C} 5 \mathrm{Cr} / \mathrm{C} 5 \mathrm{Cn} .3 \mathrm{n}$ reversal boundary (Barry et al. 2010, Kasbohm \& Schoene 2018). Near this reversal, the orbital signatures in the Most Basin weakened (nearly disappeared), as if the climate sensitivity to orbital forcing had decreased.

\section{Conclusions}

Further progress has been made in the utilisation of the unique sedimentary archive of the continental environment in the Most Basin. The use of $\mathrm{K} / \mathrm{Al}$ and $\mathrm{Mg} / \mathrm{Al}$ ratios as weathering proxies has been refined via their corrections for sediment lithology and by confirming their orbital signatures. The spatial correlation of the earliest periods of the clastic deposition in the Most Basin after the basin-wide palustrine state was extended. Several coincidences have been found between major and abrupt environmental changes in the Most Basin with magnetic polarity reversals. The earliest known lacustrine sediments in the former basin-wide peat swamp, the Bílina Delta and a proto-lake, were formed by the end of the C5Dr.2r chron and expanded during the C5Dr.1n subchron. The basin was converted to a single lake in the early part of CDr.1r. The hydrology of the basin-wide lake changed in the C5Dr/ C5Dn reversal. The change in the relative expression of orbital cycles in the Most Basin was coeval with global disruption of the Earth's climate between 17.2 and 16.9 Ma $\left(\delta^{18} \mathrm{O}\right.$ events and the onset of the MCO) and around 16.6 $\mathrm{Ma}\left(\delta^{13} \mathrm{C}\right.$ event). The latter change was coincident with new dating of the most recent large igneous provinces, the CRBG, while the former change was nearly coeval with massive acidic volcanism in the Pannonia Basin. We are not aware of the global events which could be associated with the former changes, but we are convinced that their unequivocal timing is the first step in identifying them.

\section{Acknowledgments}

The data that support the findings of this study are available from the corresponding author upon reasonable request. The work was funded by Czech Science Foundation, project numbers 16-00800S (sampling and most XRF analyses) and 19-01768S (some XRF analysis, the entire data analysis, and manuscript preparation), North Bohemian Mines (part of drill cores), and VODAMIN project (part of drill cores). The authors would like to thank to P. Schnabl and Š. Kdýr (Geological Institute, Czech Academy of Sciences, Prague, Czech Republic), who provided analyses of magnetic polarity in sediment cores used for the initial depth-age models. The authors, in particular M. Koubová are grateful to D.K. McCarty and the Chevron Energy Technology Company, a division of Chevron U.S.A. Inc., who allowed free use of the Sybilla software for academic purposes and to J.-C. Viennet for helpful comments with fitting in the Sybilla software.

\section{References}

Ait-Itto, F.-Z., Martinez, M., Price, G.D. \& Ait Addi, A. 2018. Synchronization of the astronomical time scales in the Early 
Toarcian: A link between anoxia, carbon-cycle perturbation, mass extinction and volcanism. Earth and Planetary Science Letters 493, 1-11. DOI 10.1016/j.eps1.2018.04.007

Armstrong McKay, D.I., Tyrrell, T., Wilson, P.A. \& Forster, G.L. 2015. Estimating the impact of the cryptic degassing of Large Igneous Provinces: A mid-Miocene case-study. Earth and Planetary Science Letters 403, 254-262.

DOI 10.1016/j.eps1.2014.06.040

Barry, T.L., Self, S., Kelley, S.P., Reidel, S., Hooper, P. \& Widdowson, M. 2010. New ${ }^{40} \mathrm{Ar} /{ }^{39} \mathrm{Ar}$ dating of the Grande Ronde lavas, Columbia River Basalts, USA: implications for duration of flood basalt eruption episodes. Lithos 118, 213-222. DOI 10.1016/j.lithos.2010.03.014

Beddow, H.M., Liebrand, D., Wilson, D.S., Hilgen, F.J., Sluijs, A., Wade, B.S. \& Lourens, L.J. 2018. Astronomical tunings of the Oligocene-Miocene transition from Pacific Ocean Site U1334 and implications for the carbon cycle. Climate of the Past 14, 255-270. DOI 10.5194/cp-14-255-2018

BöHme, M. 2003. The Miocene Climatic Optimum: evidence from ectothermic vertebrates of Central Europe. Palaeogeography, Palaeoclimatology, Palaeoecology 195, 389-401. DOI 10.1016/S0031-0182(03)00367-5

Buggle, B., Glaser, B., Hambach, U., Gerasimenko, N. \& MARKović, S. 2011. An evaluation of geochemical weathering indices in loess-paleosol studies. Quaternary International 240, 12-21. DOI 10.1016/j.quaint.2010.07.019

Carroll, A.R. \& Bohacs, K.M. 1999. Stratigraphic classification of ancient lakes: Balancing tectonic and climatic controls. Geology 27, 99-102. DOI10.1130/0091-7613(1999)027<0099:SCOALB $>2.3 . C O ; 2$

Chen, J., Chen, Y., Liu, L.-W., Ji, J.-F., Balsam, W., Sun, Y.B. \& Lu, H.Y. 2006. $\mathrm{Zr} / \mathrm{Rb}$ ratio in the Chinese loess sequences and its implication for changes in the East Asian winter monsoon strength. Geochimica et Cosmochimica Acta 70, 1471-1482. DOI 10.1016/j.gca.2005.11.029

Courtillot, V.E. \& Renne, P.R. 2003. On the ages of flood basalt events. Comptes Rendus Geosciences 335, 113-140. DOI 10.1016/S1631-0713(03)00006-3

De Vleeschouwer, D., Vahlenkamp, M., Crucifix, M. \& Pälike, H. 2017. Alternating Southern and Northern Hemisphere climate response to astronomical forcing during the past $35 \mathrm{~m}$.y. Geology 45, 375-378. DOI 10.1130/G38663.1

Dellisanti, F., Pini, G.A. \& Baudin, F. 2010. Use of T-max as a thermal maturity indicator in orogenic successions and comparison with clay mineral evolution. Clay Minerals 45, 115-130. DOI 10.1180/claymin.2010.045.1.115

DiLl, H.G. 2001. The geology of aluminium phosphates and sulphates of the alunite group minerals: a review. EarthScience Reviews 5, 35-93. DOI 10.1016/S0012-8252(00)00035-0

Dinis, P., Garzanti, E., Vermeesch, P. \& Huvi, J. 2017. Climatic zonation and weathering control on sediment composition (Angola). Chemical Geology 467, 110-121. DOI 10.1016/j.chemgeo.2017.07.030

Drits, V.A. \& Sakharov, B.A. 1976. X-ray analysis of mixed-layer clay minerals. 256 pp. Nauka, Moscow. [in Russian]
Drits, V.A. \& Tchoubar, C. 1990. X-ray Diffraction by Disordered Lamellar Structures. 371 pp. Springer-Verlag, Berlin. DOI 10.1007/978-3-642-74802-8

Drits, V.A., Srodon, J. \& EberL, D.D. 1997. XRD measurement ofmean crystallite thickness of illite and illite/smectite; reappraisal of the Kubler index and the Scherrer equation. Clays and Clay Minerals 45, 461-475.

DOI 10.1346/CCMN.1997.0450315

Fačevicová, K., Bábek, O., Hron, K. \& Kumpan, T. 2016. Element chemostratigraphy of the Devonian/Carboniferous boundary - A compositional approach. Applied Geochemistry 75, 211-221. DOI 10.1016/j.apgeochem.2016.10.002

Garzanti, E., Padoan, M., Peruta, L., Setti, M., Najman, Y. \& VilLA, I.M. 2013. Weathering geochemistry and Sr$\mathrm{Nd}$ fingerprints of equatorial upper Nile and Congo muds. Geochemistry Geophysics Geosystems 14, 292-316. DOI 10.1002/ggge.20060

Gasson, E., Deconto, R.M., Pollard, D. \& Levy, R.H. 2016. Dynamic Antarctic ice sheet during the early to mid-Miocene. Proceedings of the National Academy of Sciences of the United States of America 113, 3459-3464.

DOI 10.1073/pnas.1516130113

Grygar, T., Kadlec, J., Žigová, A., Mihaljevič, M., Nekutová, T., LoJKA, R. \& SvĚTLíK, I. 2009. Chemostratigraphic correlation of sediments containing expandable clay minerals based on ion exchange with $\mathrm{Cu}$ (II) complex with triethylenetetramine. Clays and Clay Minerals 57(2), 168-182. DOI 10.1346/CCMN.2009.0570204

Havelcová, M., SÝkorová, I., Bechtel, A., Mach, K., Trejtnarová, H., Žaloudková, M., Matysová, P., BlažEK, J., Boudová, J. \& Sakala, J. 2013. "Stump Horizon” in the Bílina Mine (Most Basin, Czech Republic) - GC-MS, optical and electron microscopy in identification of wood biological origin. International Journal of Coal Geology 107, 62-77. DOI 10.1016/j.coal.2012.09.008

Havelcová, M., SÝkorová, I., Mach, K, Trejtnarová, H. \& BlažEK, J. 2015. Petrology and organic geochemistry of the lower Miocene lacustrine sediments (Most Basin, Eger Graben, Czech Republic). International Journal of Coal Geology 139, 26-39. DOI 10.1016/j.coal.2014.07.003

Hilgen, F.J., Lourens, L.J. \& Van Dam, J.A. 2012. The Neogene Period. In Gradstein, F.M., OgG, J.G., Schmitz, M.D. \& OGG, G.M. (eds) The Geologic Time Scale 2012. Amsterdam, Elsevier BV. DOI 10.1016/B978-0-444-59425-9.00029-9

Holbourn, A., Kuhnt, W., Kochhann, K.G.D., Andersen, N. \& MeIER, K.J.S. 2015. Global perturbation of the carbon cycle at the onset of the Miocene Climatic Optimum. Geology 43, 123-126. DOI 10.1130/G36317.1

Ji, S.-C., Nie, J.S., Lechler, A., Huntington, K.W., Heitmann, E.O. \& BReECKer, D.O. 2018. A symmetrical $\mathrm{CO}_{2}$ peak and asymmetrical climate change during the middle Miocene. Earth and Planetary Science Letters 499, 134-144. DOI 10.1016/j.eps1.2018.07.011

Kasbohm, J. \& Schoene, B. 2018. Rapid eruption of the Columbia River flood basalt and correlation with the midMiocene climate optimum. Science Advances 4, eaat8223. DOI 10.1126/sciadv.aat8223 
Kochhann, K.G.D., Holbourn, A., Kuhnt, W., Channell, J.E.T., Lyle, M., Shackford, J.K., Wilkens, R.H. \& Andersen, N. 2016. Eccentricity pacing of eastern equatorial Pacific carbonate dissolution cycles during the Miocene Climatic Optimum. Paleoceanography 31, 1176-1192. DOI 10.1002/2016PA002988

Koller, M. \& Stahel, W.A. 2011. Sharpening Wald-type inference in robust regression for small samples. Computational Statistics and Data Analysis 55, 2504-2515.

DOI 10.1016/j.csda.2011.02.014

Kürschner, W.M., Kvaček, Z. \& Dilcher, D.L. 2008. The impact of Miocene atmospheric carbon dioxide fluctuations on climate and the evolution of terrestrial ecosystems. Proceedings of the National Academy of Sciences of the United States of America 105, 440-453.

DOI 10.1073/pnas.0708588105

Kutterolf, S., Schindlbeck, J.C., Jegen, M., Freundt, A. \& Straub, S.M. 2019. Milankovitch frequencies in tephra records at volcanic arcs: The relation of kyr-scale cyclic variations in volcanism to global climate changes. Quaternary Science Reviews 204, 1-16.

DOI 10.1016/j.quascirev.2018.11.004

Laskar, J., Robutel, P., Joutel, F., Gastineau, M., Correia, A.C.M. \& LeVrard, B. 2004. A long-term numerical solution for the insolation quantities of the Earth. Astronony and Astrophysics 428, 261-285. DOI 10.1051/0004-6361:20041335

LeVy, R. ET AL. 2016. Antarctic ice sheet sensitivity to atmospheric $\mathrm{CO}_{2}$ variations in the early to mid-Miocene. Proceedings of the National Academy of Sciences of the United States of America 113, 3453-3458.

DOI 10.1073/pnas. 1516030113

Liebrand, D., Beddow, H.M., Lourens, L.J., Pälike, H., Raffi, I., Bohaty, S.M., Hilgen, F.J., Saes, M.J.M., Wilson, P.A., Van Dijk, A.E., Hodell, D.A., Kroon., D., Huck, C.E. \& BAtenburg, S.J. 2016. Cyclostratigraphy and eccentricity tuning of the early Oligocene through early Miocene (30.1-17.1 Ma): Cibicides mundulus stable oxygen and carbon isotope records from Walvis Ridge Site. Earth and Planetary Science Letters 450, 392-405.

DOI 10.1016/j.eps1.2016.06.007

Lukács, R., Harangi, S., Guillong, M., Bachmann, O., Fodor, L., Buret, Y., Dunkl, I., Sliwinski, J., Quadt, A. von, Peytcheva, I. \& Zimmerer, M. 2018. Early to Mid-Miocene syn-extensional massive silicic volcanism in the Pannonian Basin (East-Central Europe): Eruption chronology, correlation potential and geodynamic implications. Earth-Science Reviews 179, 1-19. DOI 10.1016/j.earscirev.2018.02.005

$\mathrm{MACH}$, K. 2003. Genesis of large scale syndepositional deformations of main coal seam - Miocene Bílina delta, Most basin, Czech Republic. 83 pp. Ph.D. thesis, Charles University, Prague, Czech Republic.

Mach, K., SÝkorová, I., Konzalová, M. \& Opluštil, S. 2013. Effect of relative lake-level changes in mire-lake system on the petrographic and floristic compositions of a coal seam, in the Most Basin (Miocene), Czech Republic. International Journal of Coal Geology 105, 120-136.

DOI 10.1016/j.coal.2012.10.011
Mach, K., Teodoridis, V., Matys Grygar, T., Kvaček, Z., Suhr, P. \& Standke, G. 2014. An evaluation of paleogeography and paleoecology in the Most Basin (Czech Republic) and Saxony (Germany) from the late Oligocene to the early Miocene. Neues Jahrbuch für Geologie und Paläontologie, Abhandlungen 272(1), 13-45.

DOI 10.1127/0077-7749/2014/0395

Mach, K., Ž̇́к, K., Teodoridis, V. \& Kvaček, Z. 2017. Consequences of lower Miocene $\mathrm{CO}_{2}$ degassing on geological and paleoenvironmental settings of the Ahnikov/ Merkur Mine paleontological locality (Most Basin, Czech Republic). Neues Jahrbuch für Geologie und Palaontologie, Abhandlungen 285, 235-266.

DOI 10.1127/njgpa/2017/0680

Maechler, M., Rousseeuw, P., Croux, C., Todorov, V., Ruckstuhl, A., Salibian-Barreram, M., Verbeke, T., Koller, M., Conceicao, E.L.T. \& di Palma, M.A. 2019. Robustbase: Basic robust statistics R package version 0.93-5. URL. http:// CRAN.R-project.org/package =robustbase

Mahood, G.A. \& Benson, T.R. 2017. Using ${ }^{40} \mathrm{Ar} /{ }^{39} \mathrm{Ar}$ ages of intercalated silicic tuffs to date flood basalts: Precise ages for Steens Basalt Member of the Columbia River Basalt Group. Earth and Planetary Science Letters 459, 340-351. DOI 10.1016/j.eps1.2016.11.038

MANN, M.E. \& LeEs, J.M. 1996. Robust estimation of background noise and signal detection in climatic series. Climatic Change 33, 409-445. DOI 10.1007/BF00142586

Martinez, M., Deconinck, J.F., Pellenard, P., Reboulet, S. \& Riquier, L. 2013. Astrochronology of the Valanginian Stage from reference sections (Vocontian Basin, France) and palaeoenvironmental implications for the Weissert Event. Palaeogeography Palaeoclimatology Palaeoecology 376, 91-102. DOI 10.1016/j.palaeo.2013.02.021

Martinez, M., Deconinck, J.F., Pellenard, P., Riquier, L., Company, M., Reboulet, S. \& Moiroud, M. 2015. Astrochronology of the Valanginian-Hauterivian stages (Early Cretaceous): Chronological relationships between the Paraná-Etendeka large igneous province and the Weissert and the Faraoni events. Global and Planetary Change 131, 158-173. DOI 10.1016/j.gloplacha.2015.06.001

Matys Grygar, T. 2019. Millennial-scale climate changes manifest Milankovitch combination tones and Hallstatt solar cycles in the Devonian greenhouse world: COMMENT. Geology 47(10), e487. DOI 10.1130/G46452C.1

Matys Grygar, T. \& Mach, K. 2013. Regional chemostratigraphic key horizons in the macrofossil-barren siliciclastic lower Miocene lacustrine sediments (Most Basin, Eger Graben, Czech Republic). Bulletin of Geosciences 88, 557-571. DOI 10.3140/bull.geosci.1372

Matys Grygar, T. \& Popelka, J. 2016. Revisiting geochemical methods of distinguishing natural concentrations and pollution by risk elements in fluvial sediments. Jornal of Geochemical Exploration 170, 39-57.

DOI 10.1016/j.gexplo.2016.08.003

Matys Grygar, T., Mach, K., Pruner, P., Schnabl, P., Laurin, J. \& Martinez, M. 2014. A lacustrine record of the early stage of the Miocene Climatic Optimum in Central Europe from the 
Most Basin, Ohře (Eger) Graben, Czech Republic. Geologial Magazine 151, 1013-1033.

DOI 10.1017/S0016756813001052

Matys Grygar, T., Mach, K., Hošek, M., Schnabl, P., Martinez, M. \& Koubová, M. 2017a. Early stages of clastic deposition in the Most Basin (Ohře Rift, Czech Republic, Early Miocene): timing and possible controls. Bulletin of Geosciences 92, 337-355. DOI 10.3140/bull.geosci.1656

Matys Grygar, T., Hošek, M., Mach, K., Schnabl, P. \& Martinez, M. 2017b. Climatic instability before the Miocene Climatic Optimum reflected in a Central European lacustrine record from the Most Basin in the Czech Republic. Palaeogeography, Palaeoclimatology, Palaeoecology 485, 930-945. DOI 10.1016/j.palaeo.2017.08.011

Matys Grygar, T., Mach, K., Schnabl, P., Martinez, M. \& ZeEden, C. 2019a. Orbital forcing and abrupt events in a continental weathering proxy from central Europe (Most Basin, Czech Republic, 17.7-15.9 Ma) recorded beginning of the Miocene Climatic Optimum. Palaeogeography, Palaeoclimatology, Palaeoecology 514, 423-440.

DOI 10.1016/j.palaeo.2018.10.034

Matys Grygar, T., Mach, K. \& Martinez, M. 2019b. Checklist for the use of potassium concentrations in siliciclastic sediments as paleoenvironmental archives. Sedimentary Geology 382, 75-84. DOI 10.1016/j.sedgeo.2019.01.010

Meier, L.P. \& Kahr, G. 1999. Determination of the cation exchange capacity (CEC) of clay minerals using the complexes of copper (II) ion with triethylenetetramine and tetraethylenepentamine. Clays and Clay Minerals 47, 386-388. DOI 10.1346/CCMN.1999.0470315

Meyers, S.R. 2014. Astrochron: An R Package for Astrochronology. https://cran.r-project.org/package=astrochron

Meyers, S.R. 2019. Cyclostratigraphy and the problem of astrochronologic testing. Earth-Science Reviews 190, 190-223. DOI 10.1016/j.earscirev.2018.11.015

Miller, K.G., Baluyot, R., Wright, J.D., Kopp, R.E. \& BRownInG, J.V. 2017. Closing an early Miocene astronomical gap with Southern Ocean $\delta^{18} \mathrm{O}$ and $\delta^{13} \mathrm{C}$ records: Implications for sea level change. Paleoceanography 32, 600-621. DOI 10.1002/2016PA003074

Pawlowsky-Glahn, V., Egozcue, J.J. \& Tolosana-Delgado, R. 2015. Modeling and analysis of compositional data. 272 pp. Wiley, Chichester. DOI 10.1002/9781119003144

R Core Team 2019. R: A language and environment for statistical computing. R Foundation for Statistical Computing, Vienna, Austria. URL. http://CRAN.R-project. org/package = robustbase

RAJCHL, M., UliČNÝ, D. \& MACH, K. 2008. Interplay between tectonics and compaction in a rift-margin, lacustrine delta system: Miocene of Eger Graben, Czech Republic. Sedimentology 55, 1419-1447.

DOI 10.1111/j.1365-3091.2008.00951.x

RajChl, M., UliČNÝ, D., GRYGar, R. \& MACH, K. 2009. Evolution of basin architecture in an incipient continental rift: the Cenozoic Most Basin, Eger Graben (Central Europe). Basin Research 21(3), 269-294. DOI 10.1111/j.1365-2117.2008.00393.x
Schindlbeck, J.C., Jegen, M., Freundt, A., Kutterolf, S., Straub, S.M., Mleneck-Vautravers, M.J. \& McManus, J.F. 2018. 100-kyr cyclicity in volcanic ash emplacement: evidence from a 1.1 Myr tephra record from the NW Pacific. Scientific Reports 8, art. 4440. DOI 10.1038/s41598-018-22595-0

Sмiтн, D.G. 2019. Millennial-scale climate changes manifest Milankovitch combination tones and Hallstatt solar cycles in the Devonian greenhouse world: COMMENT. Geology 47(10), art. e488. DOI 10.1130/G46475C.1

Tanaka, K. \& Watanabe, N. 2015. Size distribution of alkali elements in riverbed sediment and its relevance to fractionation of alkali elements during chemical weathering. Chemical Geology 411, 12-18.

DOI 10.1016/j.chemgeo.2015.05.025

TAner, M.T. 2003. Attributes revisited. Rock Solid Images (RSI), Houston, Texas, 1992 revised May 2003. http://www. rocksolidimages.com/attributes-revisited/\#_Toc328470897

Thomson, D.J. 1982. Spectrum estimation and harmonic analysis. Proceedings of the IEEE 70, 1055-1096.

DOI 10.1109/PROC.1982.12433

Thomson, D.J. 1990. Quadratic-inverse spectrum estimates applications to paleoclimatology. Philosophical Transactions of the Royal Society of London Series A-Mathematical Physical and Engineering Sciences 332, 539-597.

DOI 10.1098/rsta.1990.0130

Valero, L., Cabrera, L., Saez, A. \& Garces, M. 2016. Longperiod astronomically-forced terrestrial carbon sinks. Earth and Planetary Science Letters 444, 131-138.

DOI 10.1016/j.eps1.2016.03.038

VAn DeR WeiJden, C.H. 2002. Pitfalls of normalization of marine geochemical data using a common divisor. Marine Geology 184, 167-187. DOI 10.1016/S0025-3227(01)00297-3

Vaughan, S., Bailey, R.J. \& Smith, D.G. 2011. Detecting cycles in stratigraphic data: Spectral analysis in the presence of red noise. Paleoceanography 26, PA4211.

DOI 10.1029/2011PA002195

Viennet, J.-C., Hubert, F., Ferrage, E., Tertre, E., Legout, A. \& Turpault, M.-P. 2015. Investigation of clay mineralogy in a temperate acidic soil of a forest using X-ray diffraction profile modeling: Beyond the HIS and HIV description. Geoderma 241-242, 75-86.

DOI 10.1016/j.geoderma.2014.11.004

Wu, H.-C., Zhao, X.-X., Shi, M.-N., Zhang, S.-H., Li, H.-Y. \& YANG, T.-S. 2014. A 23 Myr magnetostratigraphic time framework for Site 1148, ODP Leg 184 in South China Sea and its geological implications. Marine and Petroleum Geology 58, 749-759.

DOI 10.1016/j.marpetgeo.2014.01.003

YoHAI, V.J. 1987. High breakdown-point and high efficiency estimates for regression. The Annals of Statistics 15, 642-665. DOI 10.1214/aos/1176350366

Zachos, J., Pagani, M., Sloan, L., Thomas, E. \& Billups, K. 2001. Trends, rhythms, and aberrations in global climate 65 Ma to present. Science 292, 686-693.

DOI 10.1126/science. 1059412 